\title{
La disparidad de criterios interpretativos en torno a la casación autonómica y su enjuiciamiento constitucional en el ATC de 16 de abril de 2018 y en la STC de 29 de noviembre de 2018
}

\author{
The interpretative disparity on the regional cassation appeal and \\ its constitutional prosecution in the Order of the Constitutional \\ Court of 16 april 2018 and in the Sentence of 29 november 2018
}

\author{
Estefanía Álvarez Menéndez \\ Universidad de Oviedo (España) \\ alvarezestefania@uniovi.es
}

\section{NOTA BIOGRÁFICA}

Estefanía Álvarez Menéndez es Doctora con mención internacional por la Universidad de Oviedo y Profesora Asociada del área de Derecho Financiero y Tributario en la citada Universidad. Es miembro del Grupo de Investigación "Derecho Financiero y Tributario" dirigido por la Profesora Isabel García-Ovies Sarandeses. Su principal línea de investigación es la revisión jurisdiccional de actos en materia tributaria, y de modo particular, el recurso de casación contencioso-administrativo sobre el que ha publicado recientemente una monografía.

\section{RESUMEN}

La deficiente regulación de la casación autonómica efectuada por el artículo 86.3 LJCA, la falta de medios personales para hacer efectiva la misma y la dificultad de admitir un recurso que tiene por finalidad «formar jurisprudencia» frente a sentencias de los propios Tribunales Superiores de Justicia que establecen la misma en la instancia, ha llevado a muchos de ellos a inadmitir el recurso de casación autonómico en estos casos, mientras que otros reconocen la plena operatividad del mismo. Esta disparidad interpretativa será examinada a la vista de la jurisprudencia más actual del Tribunal Supremo acerca de la finalidad del recurso y desde una perspectiva constitucional, tras haber recaído recientes pronunciamientos que confirman la operatividad del recurso, aunque parecen relegarlo a Tribunales Superiores de Justicia de varias Salas o Secciones.

\section{PALABRAS CLAVE}

Casación autonómica; interés casacional; formación de jurisprudencia; tutela judicial efectiva.

\begin{abstract}
The deficient regulation of the regional cassation appeal made by article 86.3 LJCA, the lack of personal resources to make it effective, and the difficulty of admitting an appeal that has the purpose of «establishing jurisprudence» against the judgments of the Superior Courts of Justice that already establish it in the instance, has led many of them not to accept the regional cassation appeal in these cases, while others recognize its full operation. This interpretative disparity will be examined in view of the most current jurisprudence of the Supreme Court regarding the purpose of the cassation appeal and from a constitutional perspective, after recent pronouncements confirming the operation of this appeal, although they seem to relegate it to Superior Courts of Justice with several Chambers or Sections.
\end{abstract}


REALA. Nueva Época - N. ${ }^{\circ}$ 11, Abril-Septiembre 2019 - ISSN: 1989-8975 - DOI: 10.24965/reala.v0i11.10660 - [Págs. 75-95]

La disparidad de criterios interpretativos en torno a la casación autonómica y su enjuiciamiento constitucional en el ATC de 16 ...

Estefanía Álvarez Menéndez

\title{
KEYWORDS
}

Regional cassation appeal; cassational interest; establishing jurisprudence; effective legal protection.

\begin{abstract}
SUMARIO
1. INTRODUCCIÓN. 2. LOS PROBLEMAS DERIVADOS DE LA REGULACIÓN CASACIONAL AUTONÓMICA. 2.1. ¿QUÉ SUCEDE SI LA NORMA AUTONÓMICA PRESENTA LA MISMA REDACCIÓN QUE UNA NORMA ESTATAL? 2.2. ¿CÓMO CONSTITUIR LA SECCIÓN CASACIONAL ANTE LA FALTA DE MEDIOS PERSONALES? 3. PRINCIPAL INTERROGANTE POR DESPEJAR ANTE LA FALTA DE CLARIDAD DEL ARTÍCULO 86.3 LJCA: ¿QUÉ RESOLUCIONES SON RECURRIBLES? 3.1. LAS DISTINTAS POSTURAS DE LOS TRIBUNALES SUPERIORES DE JUSTICIA SOBRE LAADMISIÓN DEL RECURSO FRENTE A SUS PROPIAS SENTENCIAS. 3.1.1. Una postura negacionista. 3.1.2. Una postura «maximalista». 3.1.3. Un reconocimiento con condicionantes. 3.2. LA INCIERTA FINALIDAD DEL RECURSO COMO CAUSA DE LA DISPARIDAD INTERPRETATIVA: ¿FORMAR O UNIFORMAR? 4. EL ENJUICIAMIENTO CONSTITUCIONAL DE LA CASACIÓN AUTONÓMICA. 4.1. EL ATC DE 16 DE ABRIL DE 2018: LA CASACIÓN AUTONÓMICA EN TRIBUNALES SUPERIORES DE JUSTICIA DE SALA Y SECCIÓN ÚNICA. 4.1.1 Razones para una inadmisión de plano. 4.1.2. Una inadmisión razonable según nuestro Tribunal Constitucional. 4.2. LA STC DE 29 DE NOVIEMBRE DE 2018: LA CONSAGRACIÓN DE LA CASACIÓN AUTONÓMICA Y LA CONVALIDACIÓN DE SUS DEFECTOS. 4.2.1. Una regulación respetuosa con la reserva de ley orgánica prevista en el artículo 122 CE. 4.2.2. La seguridad jurídica no se ve afectada y la disparidad interpretativa de nuestros Tribunales Superiores de Justicia no vulnera el artículo 14 CE. 4.2.3. El derecho al juez predeterminado por la ley y el artículo 24 CE permanecen incólumes. 5. REFLEXIONES FINALES.
\end{abstract}

\section{INTRODUCCIÓN}

El recurso de casación experimenta un trascendental cambio de rumbo desde la reforma de la LJCA operada por la LO 7/2015. Atrás queda la reiteración hasta el desaliento de criterios jurisprudenciales sobre asuntos manidos y la ausencia de pronunciamientos sobre cuestiones de importancia capital, aunque de cuantía insuficiente. Con la normativa vigente desde el 22 de julio de 2016, al descansar la admisión del recurso en el «interés casacional objetivo para la formación de jurisprudencia», el Tribunal Supremo vestirá sus mejores galas para pronunciarse sobre aquellos temas que realmente interesan a la comunidad jurídica, ofreciendo pautas interpretativas a los órganos jurisdiccionales inferiores en busca de la unidad en la aplicación del derecho.

Ahora bien, esta labor orientadora no se ha querido confiar únicamente al Tribunal Supremo, sino que el Tribunal Superior de Justicia dentro de su ámbito jurisdiccional verá consagrada su función de último garante del derecho autonómico. Tras múltiples reivindicaciones, tendrá entre sus atribuciones el conocimiento de un recurso de casación por infracción de derecho autonómico. Al menos, eso es lo que se desprende del artículo 86.3 LJCA, no así de la LOPJ, que continúa sin reconocer dicha competencia a los Tribunales Superiores de Justicia, como tampoco lo hace el artículo 10 LJCA, que sigue aludiendo a los recursos de casación autonómicos para la unificación de doctrina y en interés de ley.

Según el artículo 86.3 LJCA, «Las sentencias que, siendo susceptibles de casación, hayan sido dictadas por las Salas de lo Contencioso-administrativo de los Tribunales Superiores de Justicia sólo serán recurribles ante la Sala de lo Contencioso-administrativo del Tribunal Supremo si el recurso pretende fundarse en infracción de normas de derecho estatal o de la Unión Europea que sea relevante y determinante del fallo impugnado, siempre que hubieran sido invocadas oportunamente en el proceso o consideradas por la Sala sentenciadora.

Cuando el recurso se fundare en infracción de normas emanadas de la Comunidad Autónoma será competente una Sección de la Sala de lo Contencioso-administrativo que tenga su sede en el Tribunal Superior de Justicia compuesta por el Presidente de dicha Sala, que la presidirá, por el Presidente o Presidentes de las demás Salas de lo Contencioso-administrativo y, en su caso, de las Secciones de las mismas, en número no superior a dos, y por los Magistrados de la referida Sala o Salas que fueran necesarios para completar un total de cinco miembros.

Si la Sala o Salas de lo Contencioso-administrativo tuviesen más de una Sección, la Sala de Gobierno del Tribunal Superior de Justicia establecerá para cada año judicial el turno con arreglo al cual los Presiden- 
REALA. Nueva Época - N. ${ }^{11}$, Abril-Septiembre 2019 - ISSN: 1989-8975 - DOI: 10.24965/reala.v0i11.10660 - [Págs. 75-95]

La disparidad de criterios interpretativos en torno a la casación autonómica y su enjuiciamiento constitucional en el ATC de 16 ...

Estefanía Álvarez Menéndez

tes de Sección ocuparán los puestos de la regulada en este apartado. También lo establecerá entre todos los Magistrados que presten servicio en la Sala o Salas».

El legislador no dedica más esfuerzos a regular la casación autonómica. Como vemos, se limita el artículo 86.3 a consagrar su existencia, a señalar cuál es el derecho a interpretar por el Tribunal Superior de Justicia y a determinar la composición de la Sección a la que se confía tal recurso. Por lo que respecta al objeto de la casación autonómica, es decir a las resoluciones recurribles, reina la incertidumbre y con ella los pareceres dispares de los distintos Tribunales Superiores de Justicia como tendremos ocasión de examinar.

Igualmente, se ha desatendido la regulación procedimental del recurso. Ante esta carencia, numerosos Tribunales Superiores de Justicia han optado por aplicar analógicamente las previsiones de la casación estatal pese a la falta identidad absoluta entre los recursos a efectos de tramitación. Pues, no olvidemos que, dada la esquizofrenia competencial que experimentan nuestros Tribunales Superiores de Justicia, estos pueden erigirse en Tribunal a quo y Tribunal Casacional en un mismo asunto, una situación que no acontece en la casación estatal y que atenta contra la nota característica de esta clase de recursos: su enjuiciamiento por un órgano «supremo» ${ }^{1}$.

Las dudas que suscita la aplicación de este recurso son numerosas. Así, trataremos aquí de enunciar los problemas que se derivan de la vigente regulación de la casación autonómica, al no haberse tenido en cuenta las posibles interferencias con el recurso de casación estatal ni la falta de medios personales que impedirá, en muchos casos, conformar la Sección Casacional, a la que se confía el citado recurso, en los términos ideados por el legislador.

Tras ello, dedicaremos nuestros esfuerzos a descifrar qué resoluciones son recurribles en casación autonómica, examinaremos los distintos pareceres de nuestros Tribunales Superiores de Justicia y su conciliación con la doctrina de nuestro Alto Tribunal sobre finalidad del recurso de casación. Asimismo, para completar nuestro estudio, analizaremos los pronunciamientos del Tribunal Constitucional que han recaído hasta el momento y que, en síntesis, convalidan los defectos que presenta la regulación del instituto aquí examinado.

\section{LOS PROBLEMAS DERIVADOS DE LA REGULACIÓN CASACIONAL AUTONÓMICA}

\section{1. ¿Qué sucede si la norma autonómica presenta la misma redacción que una norma estatal?}

Centrándonos ahora en su parca regulación, debe reconocerse el carácter problemático de la misma. Acabamos de señalar que el artículo 86.3 LJCA determina que las infracciones de derecho autonómico han de hacerse valer en casación ante los Tribunales Superiores de Justicia. Sin embargo, pudieran suscitarse dudas acerca de cuál es la norma que ha de tener tal naturaleza. Es decir, si para acceder a casación autonómica basta con que la norma que se aplique en el proceso tenga tal naturaleza o si lo determinante es que sea autonómica la norma en la que el recurrente pretenda basar su recurso.

El Tribunal Supremo ha pretendido zanjar cualquier conflicto interpretativo al respecto. Así, ha señalado en su Auto de 26 de junio de 2017 (Sala de lo Contencioso-Administrativo, Sección 1. a) (núm. Rec. 295/2017) (JUR 2017/186178) que, a efectos de determinar el órgano competente para conocer del recurso de casación, hemos de reparar en el carácter de las normas en las que pretenda basarse el recurso y no tanto en las normas aplicadas en el proceso.

Una vez determinado el carácter estatal o autonómico de la normativa infringida, cabe plantearse si, en todo caso, debiera competer la interpretación y el establecimiento de pautas interpretativas en relación con el derecho autonómico a los Tribunales Superiores de Justicia. Decimos esto porque no cabe olvidar que numerosos preceptos de derecho autonómico presentan idéntica redacción que otros de índole estatal. Así, cabe preguntarse si sería comprensible que un determinado Tribunal Superior de Justicia alcanzase una interpretación diametralmente opuesta a la del Tribunal Supremo respecto a preceptos idénticos.

No estamos ante meras elucubraciones, pues tal situación se ha dado en relación con el Impuesto sobre el Incremento de Valor de Terrenos de Naturaleza Urbana y los recientes pronunciamientos del Tribunal

Sobre las dificultades y disfunciones en la aplicación analógica de las normas reguladoras de la casación estatal a la casación autonómica, vid. ALONSO MURILLO, F. (2016): El nuevo recurso de casación contencioso-administrativo en materia tributaria, Madrid: AEDAF, núm. 9, pág. 143; RODRÍGUEZ PUÑAL, E. (2017): "La imprecisa regulación del recurso de casación autonómico", en Actualidad Jurídica Aranzadi, núm. 926, Aranzadi, pág. 1; así como RAZQUIN LIZARRAGA, J. A. (2016): "Problemas del nuevo recurso de casación contencioso-administrativo", en Revista Aranzadi Doctrinal, núm. 11, Aranzadi, pág. 4. 
REALA. Nueva Época - N. 11, Abril-Septiembre 2019 - ISSN: 1989-8975 - DOI: 10.24965/reala.v0i11.10660 - [Págs. 75-95]

La disparidad de criterios interpretativos en torno a la casación autonómica y su enjuiciamiento constitucional en el ATC de 16 ...

Estefanía Álvarez Menéndez

Constitucional acerca de la posibilidad de someter a gravamen situaciones inexpresivas de capacidad económica. El Tribunal Superior de Justicia de Navarra interpreta que la STC 72/2017, de 5 de junio, recaída en interpretación del derecho foral navarro, declara la inconstitucionalidad radical de los artículos 175.2, 175.3 y 178.4 de la LF de Haciendas Locales². Según su entender, al haber sido expulsados del ordenamiento jurídico dichos preceptos, no existe amparo legal para determinar si se ha producido o no incremento de valor del terreno y, por tanto, las liquidaciones practicadas por tal concepto devienen nulas.

No es nuestra intención hacer una valoración del acierto o desatino de su fundamentación, sino poner de manifiesto que, en interpretación de la STC 59/2017, de 11 de mayo, que se pronuncia sobre la normativa reguladora de Haciendas Locales en territorio común, en términos prácticamente idénticos a la ya mencionada STC 72/2017, de 5 de junio, el Tribunal Supremo ha optado por una tesis minimalista.

En concreto, señala nuestro Alto Tribunal, entre otras, en la Sentencia de 20 de diciembre de 2018 (Sala lo Contencioso-Administrativo, Sección 2. ${ }^{\text {) }}$ (núm. Rec. 4980/2017) (JUR 2019/6113), que no puede compartir el criterio defendido anteriormente, puesto que el Tribunal Constitucional tan solo ha declarado la inconstitucionalidad total del artículo 110.4 TRLRHL. Según su parecer, los artículos 107.1 y 107.2 TRLHL estarían afectados por una inconstitucionalidad parcial. Este entendimiento le lleva a mantener una tesis minimalista y a defender que ha de ser el recurrente el que pruebe la inexistencia de incremento de valor del terreno, en cuyo caso no procederá liquidación alguna. En caso contrario, se girará la correspondiente liquidación de acuerdo con lo dispuesto en los artículos 107.1 y 107.2 anteriormente mencionados.

Es más, realiza nuestro Tribunal Supremo una crítica evidente a la posición defendida por el Tribunal Superior de Justicia de Navarra, al señalar lo siguiente: «tenemos que refutar a continuación la interpretación excesivamente literal -y, lo que es más reprobable, asistemática- que algunos Tribunales Superiores de Justicia vienen efectuando de la letra c) del FJ 5 de la STC 59/2017, que les lleva a transformar el que es el entendimiento correcto del fallo de la Sentencia -la declaración de inconstitucionalidad parcial de los artículos 107.1 y 107.2 a) del TRLHL- en una comprensión errónea del mismo: en particular, a defender la declaración de inconstitucionalidad radical y absoluta de los mencionados preceptos y, por derivación, a descartar a radice que, hasta tanto se produzca la reforma legal del IIVTNU, puedan girarse liquidaciones correspondientes al mismo... La doctrina sentada por los Tribunales Superiores de Justicia a la que nos venimos refiriendo desconoce - 0 , al menos, lo pasa por alto- el corolario que se desprende de la declaración de inconstitucionalidad total del artículo 110.4 TRLHL».

Resulta paradójico que, ante idéntica redacción de los preceptos a aplicar y existiendo pronunciamientos constitucionales en la misma línea, se alcance tal disparidad interpretativa, según se trate de derecho autonómico o derecho estatal. El Tribunal Supremo critica abiertamente la tesis maximalista adoptada por los Tribunales Superiores de Justicia, pero lo cierto es que no será sencillo alcanzar la paz interpretativa en estas cuestiones dada la falta de cauce para ello.

Así, debemos tener presente que las sentencias dictadas en instancia por los Tribunales Superiores de Justicia de territorio común que adoptan una tesis maximalista pueden ser recurridas en casación ante el Tribunal Supremo, pero las sentencias dictadas en casación autonómica, como es el caso de las STSJ de Navarra anteriormente citadas, no tienen oportunidad alguna de ser recurridas ante el Tribunal Supremo al considerarse que son los Tribunales Superiores de Justicia los últimos garantes del derecho autonómico.

La inseguridad está servida y más aún si tenemos en cuenta que no cabe descartar de manera rotunda que puedan alcanzarse distintas interpretaciones en relación a los mismos preceptos de derecho autonómico. Ello es debido a que el Tribunal Supremo mantiene, tras la reforma casacional, su doctrina acerca de la admisión del recurso de casación estatal por infracción de derecho autonómico en determinados supuestos. Nos estamos refiriendo a la admisión de la casación estatal cuando se infrinja derecho autonómico que reproduzca derecho estatal de carácter básico o en aquellos supuestos en que se infringe la jurisprudencia del Tribunal Supremo recaída sobre preceptos de derecho estatal que presentan la misma redacción que los autonómicos en liza, aunque no tengan carácter básico.

Esta doctrina clásica ha sido recientemente reproducida por el ATS de 6 de marzo de 2018 (Sala de lo Contencioso-Administrativo, Sección 1.a) (núm. Rec. 580/2017) (JUR 2018/80930), y explicada bajo la premisa de que «el valor de complementar el ordenamiento jurídico que el artículo 1.6 del Código Civil otorga a la jurisprudencia no desaparece por la existencia de derecho autonómico».

2 Al respecto, vid., entre otras resoluciones del Tribunal Superior de Justicia de Navarra, la STSJ de 29 de octubre de 2017 (Sala de lo Contencioso-Administrativo) (núm. Rec. 309/2016) (JT 2017/1343); así como la STSJ de 6 de febrero de 2018 (Sala de lo Contencioso-Administrativo, Sección 1. ${ }^{a}$ ) (núm. Rec. 535/2016) (JT 2018/160) del citado Tribunal, que ha recaído en casación autonómica. 
Así pues, podría darse el caso de que se recurriese ante el Tribunal Supremo, por infracción de doctrina jurisprudencial, una sentencia dictada en el ámbito jurisdiccional navarro, que comulgue con la tesis mantenida por el Tribunal Superior de Justicia de Navarra en relación con el Impuesto sobre el Incremento de Valor de Terrenos de naturaleza urbana, siendo dicha sentencia casada por el Tribunal Supremo. Y, paradójicamente, de haberse recurrido esta en casación autonómica, no se estimaría el recurso interpuesto ante el Tribunal Superior de Justicia de Navarra.

Aunque se trata de una medida que no estaría exenta de polémica, debiera reflexionarse sobre la posibilidad de encomendar al Tribunal Supremo el conocimiento de aquellos recursos en los que se hace valer la infracción de un precepto de derecho autonómico de contenido idéntico al derecho estatal, sustrayendo la competencia a los Tribunales Superiores de Justicia en dichos casos ${ }^{3}$.

\section{2. ¿Cómo constituir la Sección Casacional ante la falta de medios personales?}

La primera cuestión regulada en el artículo 86.3 LJCA constituye ya un problema. Sin embargo, no es el único que plantea la escueta regulación de la casación autonómica. La Sección competente para conocer del recurso de casación autonómico se ha configurado con abstracción de la realidad jurisdiccional. Es decir, obviando la falta de medios personales.

Según el artículo 86.3.2. ${ }^{\circ}$ párrafo de la LJCA, dicha Sección Casacional ha de estar compuesta por cinco miembros pertenecientes al orden contencioso-administrativo. Pues bien, si se reconoce la operatividad del recurso frente a sentencias del propio Tribunal Superior de Justicia, esta previsión sería difícilmente realizable, máxime si estos se organizan en Sala y Sección Única.

El hecho de que el Tribunal Superior de Justicia pueda ser Tribunal a quo y Tribunal Casacional trae consigo importantes problemas de contaminación. Los Magistrados que adoptaron la decisión en la instancia no deben tomar parte en el enjuiciamiento casacional. Si a ello añadimos la aludida falta de medios, no quedará más remedio que acudir a continuas sustituciones o, incluso, constituir permanentemente la Sección Casacional con Magistrados de otros órdenes jurisdiccionales, cuando el problema de medios personales sea aún más acuciante. Curiosa esta última solución, puesto que podría darse el caso de que Magistrados no especialistas enmendasen la decisión adoptada en la instancia por Magistrados especialistas. Amén de que esta opción supone desoír el mandato legislativo, pues la LJCA dispone que los miembros que integren la citada Sección han de pertenecer al orden contencioso-administrativo ${ }^{4}$.

\section{PRINCIPAL INTERROGANTE POR DESPEJAR ANTE LA FALTA DE CLARIDAD DEL ARTÍCULO 86.3 LJCA: ¿QUÉ RESOLUCIONES SON RECURRIBLES?}

La regulación de la casación autonómica presenta deficiencias, pero también deja en el aire cuestiones de vital importancia, entre ellas, la determinación del objeto del recurso. El artículo $86.3,1 .^{\circ}$ y $2 .^{\circ}$ párrafo, señala que «las sentencias que, siendo susceptibles de casación, hayan sido dictadas por las Salas de lo Contencioso-administrativo de los Tribunales Superiores de Justicia sólo serán recurribles ante la Sala de lo Contencioso-administrativo del Tribunal Supremo si el recurso pretende fundarse en infracción de normas de Derecho estatal o de la Unión Europea que sea relevante y determinante del fallo impugnado, siempre que hubieran sido invocadas oportunamente en el proceso o consideradas por la Sala sentenciadora.

${ }^{3}$ En la práctica y tras entrar en vigor el nuevo recurso de casación, el Tribunal Supremo ha flexibilizado, en ocasiones, la doctrina expuesta y ha admitido recursos de casación por infracción de normativa autonómica idéntica a la estatal, aun cuando no se tratase de derecho estatal básico ni hubiese, en el momento de admisión, jurisprudencia consolidada que hubiese recaído en interpretación del derecho estatal de contenido idéntico. Al respecto, vid. ATS de 31 de octubre de 2017 (Sala de lo ContenciosoAdministrativo, Sección 1. ${ }^{a}$ ) (núm. Rec. 2913/2017) (JUR 2018/3936), que precisamente admite un recurso de casación frente a una Sentencia del Tribunal Superior de Justicia del País Vasco a los efectos de determinar si «se produce o no el hecho imponible del impuesto sobre el incremento de valor de los terrenos de naturaleza urbana cuando el interesado pueda acreditar la inexistencia de un aumento real del valor del terreno en la fecha del devengo del impuesto». Otros ejemplos de flexibilización de su doctrina pueden encontrarse en el ATS de 5 de abril de 2017 (Sala de lo Contencioso-Administrativo, Sección 1. a) (núm. Rec. 404/2017) (JUR 2017/81598) y en el ATS de 24 de mayo de 2017 (Sala de lo Contencioso-Administrativo, Sección 1.å) (núm. Rec. 767/2017) (JUR 2017/152317).

4 Para un estudio en profundidad de los problemas que plantea el reconocimiento del recurso frente a las sentencias de los Tribunales Superiores de Justicia, vid. ÁLVAREZ MENÉNDEZ, E. (2018): "El recurso de casación autonómico", en El recurso de casación en materia tributaria, Cizur Menor: Aranzadi. 
REALA. Nueva Época - N. ${ }^{\circ}$ 11, Abril-Septiembre 2019 - ISSN: 1989-8975 - DOI: 10.24965/reala.v0i11.10660 - [Págs. 75-95]

La disparidad de criterios interpretativos en torno a la casación autonómica y su enjuiciamiento constitucional en el ATC de 16 ...

Estefanía Álvarez Menéndez

Cuando el recurso se fundare en infracción de normas emanadas de la Comunidad Autónoma será competente una Sección de la Sala de lo Contencioso-administrativo que tenga su sede en el Tribunal Superior de Justicia».

Podemos plantearnos si ha de efectuarse una lectura complementaria de estos párrafos, de tal modo que solo puedan recurrirse las sentencias de los Tribunales Superiores de Justicia; o si ha de optarse por una lectura independiente, no pudiendo descartarse la casación autonómica frente a sentencias de los Juzgados de lo Contencioso-Administrativo ${ }^{5}$.

Aunque es una cuestión que se presta a interpretación, lo cierto es que, de manera unánime, los Tribunales Superiores de Justicia que reconocen la operatividad del recurso de casación autonómico coinciden en que las sentencias de los Juzgados de lo Contencioso-Administrativo son susceptibles de casación autonómica. No en vano, son el objeto natural de este recurso, permitiendo a los Tribunales Superiores de Justicia establecer doctrina en aquellas cuestiones que, por falta de cuantía, no acceden a los mismos en apelación.

Menos uniformidad encontramos a la hora de reconocer el recurso de casación autonómico frente a las sentencias de los Tribunales Superiores de Justicia. Y no es de extrañar, en cierto modo, pues, aunque el tenor legislativo nos lleva a considerarlas como objeto del citado medio impugnatorio, son múltiples los obstáculos que encontraríamos a la hora de admitir el recurso si siguiésemos estrictamente el mandato legislativo. No olvidemos que el nuevo recurso de casación se orienta a la "formación de jurisprudencia» y esta se establece ya por el Tribunal Superior de Justicia al conocer del litigio en la instancia ${ }^{6}$.

Asimismo, a la eventual falta de idoneidad del recurso frente a sentencias del propio Tribunal Superior de Justicia para el cumplimiento de la finalidad encomendada, habría que sumar las disfunciones que se ocasionan con su reconocimiento. Una de ellas se presentaría a la hora de aplicar analógicamente a la casación autonómica la regulación procedimental del recurso de casación estatal, dado que esta descansa sobre una nota característica de todo recurso de casación: la diferenciación entre Tribunal a quo y Tribunal Casacional.

Igualmente, reconocer el carácter recurrible de estas resoluciones supone que la composición de la Sección Casacional sea de difícil o imposible constitución en determinados Tribunales Superiores de Justicia. El problema de la contaminación no se presenta cuando el recurso se interpone frente a sentencias de los Juzgados de lo Contencioso-Administrativo.

\subsection{Las distintas posturas de los Tribunales Superiores de Justicia sobre la admisión del recurso frente a sus propias sentencias}

Por las razones anteriormente expuestas y especialmente por la incertidumbre que genera la finalidad del recurso de casación, que ni siquiera el Tribunal Supremo ha despejado con la suficiente claridad, encontramos distintas posturas de nuestros Tribunales Superiores de Justicia respecto al carácter recurrible de sus sentencias en casación autonómica.

\footnotetext{
${ }^{5}$ Sobre esta cuestión ha debatido la doctrina sin que pueda considerarse que existe una posición unánime al respecto. Así, ha habido autores que, dados los términos en los que se redacta el artículo 86.3 LJCA, únicamente reconocen el recurso de casación autonómico frente a las sentencias de los Tribunales Superiores de Justicia. Al respecto, vid. QUINTANA CARRETERO, J. P., CASTILLO BADAL, R. y ESCRIBANO TESTAUT, P. (2016): Guía Práctica del recurso de casación contencioso-administrativo (coord. QUINTANA CARRETERO, J. P.), Madrid: Dykinson, pág. 400; así como ALONSO MURILLO, F., quien señala, no obstante, que la tesis favorable a reconocer el recurso frente a sentencias de los Juzgados de lo contencioso-administrativo no puede ser «descartada en una interpretación lógica y sistemática de los apartados 1 y 3 del artículo 86 de la LJCA, pero plantea el problema de salvar el escollo que supone la aplicación del viejo aforismo in claris non fit interpretatio». En su opinión, «urge la modificación legal, porque sólo al legislador compete rectificar sus errores u olvidos», "El nuevo recurso de casación contencioso-administrativo en materia tributaria", op. cit., pág.143.

Por su parte, ha habido otros autores que se muestran partidarios de reconocer el recurso también frente a las sentencias de los Juzgados de lo Contencioso-Administrativo. Al respecto, vid. CHAVES GARCíA, J. R., "Si un extraterrestre observase el recurso de casación contencioso-administrativo", dirección URL: https://delajusticia.com/2017/03/24/si-un-extraterrestre-observase-el-recurso-decasacion-contencioso-administrativo/, pág. 3; así como RIVERO GONZÁLEZ, M. (coord.) (2012): "El nuevo régimen de los recursos extraordinarios en la jurisdicción contencioso-administrativa", en Comentarios a la Ley de la Jurisdicción Contencioso-Administrativa de 1998, 5. ${ }^{\mathrm{a}}$ ed., Pamplona: Aranzadi, pág. 10.

Esta última interpretación es la más razonable también para RODRÍGUEZ PUÑAL, E., "La imprecisa regulación del recurso de casación autonómico", op. cit., pág. 1; así como para CUDERO BLAS, J., "El recurso de casación por infracción de normas autonómicas", en El Derecho, dirección URL: http://www.elderecho.com/tribuna/administrativo/recurso-casacion-infraccion-normas-autonomicas_11_982180001.html, pág. 4.

6 Señalaba REQUERO IBÁÑEZ, J. L., que sería innecesario arbitrar un recurso que tenga por finalidad la formación de jurisprudencia, pues el Tribunal Superior de Justicia ya establece esta al pronunciarse en la instancia sobre la cuestión, vid. "La reforma de 2015 del recurso de casación en la jurisdicción contencioso-administrativa”, en Cuadernos Digitales de Formación, núm. 25, Consejo General del Poder Judicial, 2016, pág. 16.
} 
La discrepancia ha llegado al punto de que ha habido Tribunales Superiores de Justicia que han negado la operatividad del recurso de casación autonómico en su ámbito jurisdiccional. Otros han defendido que el recurso de casación autonómico no puede interponerse frente a sus propias sentencias, sino que únicamente cabe frente a las sentencias de los Juzgados de lo Contencioso-Administrativo. Los hay que reconocen el recurso en toda su extensión y también otros que limitan la finalidad con la que puede ser interpuesto el recurso frente a las sentencias de los Tribunales Superiores de Justicia. Es tal el desconcierto y la falta de entendimiento que, incluso, algunos no imponen costas en caso de inadmisión del citado medio impugnatorio, pese a preverse dicha imposición en el artículo 90.8 LJCA que se aplica analógicamente ${ }^{7}$.

\subsubsection{Una postura negacionista}

Así, en el ámbito jurisdiccional de Cataluña solo se reconoce el recurso de casación autonómico frente a sentencias de los Juzgados de lo Contencioso-Administrativo. El ATSJ de 10 de mayo de 2017 (Sala de lo Contencioso-Administrativo, Sección 6. ${ }^{a}$ ) (núm. Rec. 3/2017) (JUR 2017/140717) defiende que el citado recurso no puede interponerse frente a sentencias del propio Tribunal ya que en ese caso existiría una prevalencia de la Sección Casacional que carece de soporte en la legislación orgánica judicial. Incluso, podría ser esta contradictoria con el artículo 264 LOPJ que confía al Pleno la unificación de criterios. Asimismo, considera dicho Tribunal Superior de Justicia que admitir la casación frente a dichas sentencias sería contradictorio con el procedimiento establecido para la casación estatal, que prevé una Sección de admisión diferenciada de la Sección encargada del enjuiciamiento en casación.

Igualmente, siguiendo sus propias palabras, su reconocimiento comportaría que una Sección especializada viese revisada su interpretación por una Sección que pudiera ser no especializada y de composición rotatoria. A lo que ha de sumarse el hecho de que el nuevo recurso de casación no se contemple frente a las sentencias del Tribunal Supremo, lo que, a su juicio, no hace sino reforzar la postura de que el recurso no está configurado para interponerse frente a sentencias de la misma Sala o Tribunal. Es más, permitirlo traería consigo un importante problema de contaminación de Magistrados por falta de medios personales.

Además, como uno de los argumentos de cierre, señala el Tribunal Superior de Justicia que admitir el recurso de casación frente a sentencias del propio Tribunal supondría incumplir la finalidad encomendada al recurso de casación, que no es otra que la de «formar jurisprudencia».

Si seguimos fielmente el mandato legislativo, que exige admitir el recurso cuando este presente interés casacional objetivo "para la formación de jurisprudencia», puede que no le falte razón al Tribunal Superior de Justicia de Cataluña. No obstante, no consideramos que quepa una inadmisión de plano, pues el propio tenor literal no excluye la recurribilidad de dichas sentencias. A nuestro juicio, debiera abordarse el examen sobre su admisibilidad y la eventual concurrencia de «interés casacional objetivo para la formación de jurisprudencia». Es cierto que será difícil que este concurra en estos casos, pero no puede descartarse plenamente a la vista de la jurisprudencia de nuestro Tribunal Supremo.

\subsubsection{Una postura "maximalista»}

En una postura antitética, encontramos Tribunales Superiores de Justicia que reconocen el recurso de casación autonómico en toda su extensión. Es el caso, entre otros, de Asturias, Aragón o Navarra, que admiten el recurso frente a sus propias sentencias sin limitar los supuestos o presunciones de interés casacional que el recurrente puede esgrimir.

7 Al respecto, el Tribunal Superior de Justicia de Valencia en su Auto de 1 de diciembre de 2017 (Sala de lo Contencioso-Administrativo, Sección 1. ${ }^{a}$ ) (núm. Rec. 351/2017) (JUR 2017/301503) señala lo siguiente: «Siguiendo el mismo criterio que el citado auto de 20 de julio de 2.017, no procede pronunciamiento en costas, pues como en aquel se dice: "Habida cuenta de lo novedoso de la cuestión jurídica tratada y -sobre todo- las dificultades de interpretación que presenta la nueva casación autonómica (directamente derivadas de la ausencia de una regulación mínimamente completa de la misma), entendemos procedente hacer uso de la facultad conferida por el último inciso del apartado 1 del art. 139 LJCA (RCL 1998, 1741), de manera que no efectuaremos pronunciamiento sobre las costas procesales"...». En análogo sentido, el Tribunal Superior de Justicia de Galicia tampoco impone costas, pese al pronunciamiento de inadmisión del recurso, en su Auto de 5 de julio de 2017 (Sala de lo Contencioso-Administrativo, Sección 2. ${ }^{\text {a) }}$ (núm. Rec. 4184/2017) (JUR 2018/38752) que señala lo siguiente: «Ha de traerse a este recurso, por razón de unidad de criterio, el pronunciamiento que se recoge en el Auto de esta Sección de 22 de junio pasado sobre costas, y es que aun cuando el artículo 90.8 LJCA (RCL 1998, 1741) establece que la inadmisión a trámite del recurso de casación comportará la imposición de las costas a la parte recurrente, este precepto complementado con lo dispuesto en el artículo 139.2 LJCA, lleva a este órgano jurisdiccional a considerar procedente no efectuar imposición de costas en atención a las dudas interpretativas sobre la nueva regulación del recurso de casación». 
Incluso, cabe la invocación de la presunción contenida en el artículo 88.3 a) LJCA - «cuando en la resolución impugnada se hayan aplicado normas en las que se sustente la razón de decidir sobre las que no exista jurisprudencia» ${ }^{8}$. Esta posibilidad pudiera resultar un tanto paradójica si tenemos en cuenta que el Tribunal Superior de Justicia ya se ha pronunciado sobre la cuestión en la instancia. Es cierto, no obstante, que no podemos descartarla plenamente mientras sigan existiendo pronunciamientos de nuestro Alto Tribunal que exigen la reiteración, la existencia de dos o más pronunciamientos sobre la cuestión, para que pueda hablarse propiamente de jurisprudencia? .

\subsubsection{Un reconocimiento con condicionantes}

Por su parte, el Tribunal Superior de Justicia de Madrid, entre otros, en el Auto de 17 de mayo de 2017 (Sala de lo Contencioso-Administrativo, Sección 100.a) (núm. Rec. 10/2017) (JUR 2017/122924), abre una vía de interpretación intermedia que es seguida mayoritariamente por nuestros Tribunales Superiores de Justicia ${ }^{10}$ y que podría resumirse del siguiente modo: habida cuenta de que una interpretación literal del artículo 86.3 LJCA no puede llevarnos a descartar de plano la admisión del recurso de casación frente a las sentencias de los Tribunales Superiores de Justicia, y reconociendo que la «jurisprudencia menor» se establece ya en la instancia por el Tribunal, el recurso de casación autonómico solo puede admitirse a los efectos de depurar contradicciones, ya sea porque concurra el supuesto de interés casacional objetivo previsto en el artículo 88.2 a) o la presunción enunciada en el artículo 88.3. b) LJCA.

Es loable este intento de conciliar el reconocimiento del recurso de casación autonómico frente a sentencias de los Tribunales Superiores de Justicia con el hecho innegable de que ya ha habido pronunciamiento sobre la cuestión en la instancia; ahora bien, dudamos de que esta postura sea acorde a la intención legislativa. El recurso se orienta a la "formación de jurisprudencia», no propiamente a la depuración de contradicciones, como lo demuestra también el hecho de que no se articule un recurso de casación estatal frente a las sentencias del propio Tribunal Supremo.

Ha habido otros Tribunales Superiores de Justicia, como es el caso de Cantabria, que han sido más cautos en este sentido y han tratado de mantener el recurso de casación autonómico frente a sentencias de los Tribunales Superiores de Justicia siguiendo una argumentación conforme a la doctrina mayoritaria del Tribunal Supremo, que examinaremos a continuación. Así, entre otros, en el Auto de 6 de febrero de 2018 (Sala de lo Contencioso-Administrativo, Sección 1. ${ }^{a}$ ) (núm. Rec. 263/2017) (JUR 2018/59895) ha señalado que la existencia de pronunciamiento previo sobre la cuestión en la instancia no empece la admisión del recurso de casación autonómico, pues pudiera ser necesario que el Tribunal Superior de Justicia matice, aclare, precise o corrija su doctrina ${ }^{11}$.

${ }^{8}$ En este sentido, vid. ATSJ de 18 de abril de 2017 (Sala de lo Contencioso-Administrativo, Sección 1. ${ }^{\text {a) }}$ (núm. Rec. 3/2016) (JUR 2017/127831).

Como se ha expuesto líneas antes, los Tribunales Superiores de Justicia de Aragón y Navarra tampoco limitan los supuestos o presunciones de interés casacional objetivo que cabe invocar en el recurso de casación autonómico. Al respecto, vid. ATSJ de Navarra de 9 de marzo de 2018 (Sala de lo Contencioso-Administrativo, Sección 1. a) (núm. Rec. 515/2017) (JUR 2018/136309), así como los AATSJ de Aragón de 28 de marzo de 2018 (Sala de lo Contencioso-Administrativo) (núm. Rec. 50/2018) (JUR 2018/99800) y (núm. Rec. 19/2018) (JUR 2018/99606).

${ }^{9}$ Resulta sumamente ilustrativo el ATS de 30 de mayo de 2017 (Sala de lo Contencioso-Administrativo, Sección 1. ${ }^{\text {a) }}$ (núm. Rec. 875/2017) (JUR 2017/139555) que señala lo siguiente: «En cualquier caso, la existencia de una única sentencia de este Tribunal hace aconsejable -para formar jurisprudencia mediante la doctrina reiterada a la que se refiere el artículo 1.6 del Código Civil- que la Sala se pronuncie para reafirmar, reforzar o completar aquel criterio o, en su caso, para cambiarlo o corregirlo en los términos -en ambos supuestos- que la Sección de Enjuiciamiento tenga por conveniente». En sentido análogo se pronuncia el ATS de 16 de mayo de 2017 (Sala de lo Contencioso-Administrativo, Sección 1. ${ }^{a}$ ) (núm. Rec. 685/2017) (JUR 2017/117424), el ATS de 29 de mayo de 2017 (Sala de lo Contencioso-Administrativo, Sección 1. ${ }^{a}$ ) (núm. Rec. 702/2017) (JUR 2017/148843) y, entre otros, el ATS de 6 de junio de 2017 (Sala de lo Contencioso-Administrativo, Sección 1. ${ }^{\text {a) }}$ (núm. Rec. 1137/2017) (JUR 2017/145886).

Si la jurisprudencia es producto de la reiteración, no alcanzamos a entender pronunciamientos como los contenidos en el ATS de 17 de julio de 2017 (Sala de lo Contencioso-Administrativo, Sección 1. ${ }^{a}$ ) (núm. Rec. 1319/2017) (JUR 2017/238400). En dicho Auto se inadmite un recurso de casación, pese a que únicamente existía un pronunciamiento previo sobre la cuestión, al entender que la jurisprudencia se encontraba establecida sin que fuese necesario matizarla, precisarla o concretarla.

10 La interpretación manejada por el Tribunal Superior de Justicia de Madrid, en el sentido de que el recurso de casación autonómico frente a sus propias sentencias solo puede admitirse a los efectos de depurar contradicciones, es seguida por sus homólogos de Castilla y León (ATSJ de 11 de octubre de 2017 (Sala de lo Contencioso-Administrativo, Burgos) (núm. Rec. 106/2017) (JUR 2017/ 295151), País Vasco (ATSJ de 24 de febrero de 2017 (Sala de lo Contencioso-Administrativo, Sección 3..$^{\text {) }}$ (núm. Rec. 1/2017) (JUR 2017/139721) y, entre otros, Valencia (ATSJ de 1 de diciembre de 2017 (Sala de lo Contencioso-Administrativo, Sección 1. ${ }^{a)}$ (núm. Rec. 351/2017) (JUR 2017/301503).

11 El Tribunal Superior de Justicia de Galicia apuesta igualmente por admitir el recurso frente a dichas sentencias a los efectos de matizar o precisar la doctrina existente para adaptarla a nuevas realidades. No obstante, según su criterio, también cabe admitir el 


\subsection{La incierta finalidad del recurso como causa de la disparidad interpretativa: ¿formar o uniformar?}

Son numerosas las dudas que se plantean a la hora de articular un recurso de casación autonómico frente a las sentencias de los Tribunales Superiores de Justicia, y la causa, como hemos adelantado y aquí ha quedado constatado, no es otra que el desconocimiento de la finalidad encomendada al nuevo recurso de casación. Una cuestión esta sobre la que tampoco el Tribunal Supremo ha arrojado demasiada luz. Es cierto que puede vislumbrarse su posición mayoritaria, pero también lo es que cabe encontrar múltiples excepciones a la misma. Su estudio interesa a los efectos de comprobar si tienen cabida los distintos posicionamientos de nuestros Tribunales Superiores de Justicia respecto a la admisión de la casación autonómica frente a sus propias sentencias.

Con carácter general, el Tribunal Supremo ha sostenido que el interés casacional objetivo, que exige el recurso de casación para ser admitido, ha de serlo para la formación de jurisprudencia ${ }^{12}$. Desde esa perspectiva, que sería conforme al mandato legislativo por más desafortunado que resulte supeditar la depuración de contradicciones a la formación de jurisprudencia, si existe jurisprudencia consolidada sobre la cuestión no se apreciará, con carácter general, la existencia de interés casacional objetivo «para la formación de jurisprudencia» ${ }^{13}$.

Así, entre otros, el ATS de 6 de junio de 2018 (Sala de lo Contencioso-Administrativo, Sección 1. ${ }^{\text {a) }}$ (núm. Rec. 2037/2018) (JUR 2018/169225) ha señalado que «si la jurisprudencia está formada y consolidada sólo la cuidadosamente justificada necesidad de matizarla, precisarla, concretarla o incluso de corregirla justificaría la conveniencia de un nuevo pronunciamiento del Tribunal Supremo» ${ }^{14}$.

Si uno se detiene en el examen de la finalidad del recurso de casación enunciada por la LJCA e interpretada rectamente en estos pronunciamientos, parece que no debieran tener cabida planteamientos como los del Tribunal Superior de Justicia de Madrid en lo que respecta a la admisión del recurso frente a sus propias sentencias.

Recordemos que dicho Tribunal, en una interpretación extendida por nuestro territorio nacional, defiende que en esos casos solo debe admitirse el recurso de casación autonómico para depurar contradicciones. Pues bien, habida cuenta de lo manifestado líneas antes, la finalidad del nuevo recurso de casación no es depurar contradicciones, sino establecer jurisprudencia y el propio Tribunal Superior de Justicia de Madrid sostiene que dicho cometido no podrá cumplirse cuando el recurso de casación se dirija frente a sus propias sentencias por establecerse ya esta cuando se conoce del litigio en la instancia.

Tampoco parece que pudieran acogerse, a la luz del posicionamiento de nuestro Tribunal Supremo, aquellos planteamientos de Tribunales Superiores de Justicia que reconocen el recurso de casación autonómico frente a sus propias sentencias en toda su extensión. En último término, habrá de examinarse si el recurso puede cumplir con la finalidad de «formación de jurisprudencia», y, de entrada, ello presenta dificultades al establecerse la doctrina en la instancia.

Ahora bien, quizás tampoco debiera tener cabida la inadmisión de plano de los recursos de casación autonómicos frente a las sentencias de los Tribunales Superiores de Justicia, y ello, por dos motivos que se desprenden de los pronunciamientos de nuestro Alto Tribunal. El primero de ellos es que, aun estando establecida la jurisprudencia, pudiera ser necesario precisarla, matizarla o corregirla. Cierto es que se nos hace difícil imaginar esta hipótesis cuando el Tribunal Superior de Justicia acaba de pronunciarse sobre la cuestión en la instancia.

El segundo guarda relación con la línea interpretativa que, como hemos visto, maneja el Tribunal Supremo sobre el concepto de jurisprudencia. Puede que únicamente haya recaído sobre la cuestión un pronunciamiento del Tribunal Superior, el de la instancia, siendo necesario un segundo pronunciamiento para que

\footnotetext{
mismo a los efectos de depurar contradicciones. En este sentido puede consultarse, entre otros, el ATSJ de 5 de julio de 2017 (Sala de lo Contencioso-Administrativo, Sección 2. ${ }^{a}$ ) (núm. Rec. 4184/2017) (JUR 2018/38752).

12 Al respecto, vid. ATS de 5 de abril de 2017 (Sala de lo Contencioso-Administrativo, Sección 1. ${ }^{\text {a) }}$ (núm. Rec. 628/2017) (JUR 2017/81588).

13 Señalaba el ATS de 20 de febrero de 2017 (Sala de lo Contencioso-Administrativo, Sección 1. ${ }^{a}$ ) (núm. Rec. 118/2016) (JUR 2017/47267) que «no cabe acoger ninguno de los supuestos invocados con base en este precepto legal, porque al existir una consolidada jurisprudencia sobre la cuestión controvertida establecida con carácter general... no se aprecia la existencia de interés casacional objetivo para la formación de jurisprudencia».

${ }_{14}$ Asimismo, vid. ATS de 23 de mayo de 2018 (Sala de lo Contencioso-Administrativo, Sección 1. a) (núm. Rec. 527/2018) (JUR 2018/154577).
} 
REALA. Nueva Época - N. ${ }^{11}$, Abril-Septiembre 2019 - ISSN: 1989-8975 - DOI: 10.24965/reala.v0i11.10660 - [Págs. 75-95]

La disparidad de criterios interpretativos en torno a la casación autonómica y su enjuiciamiento constitucional en el ATC de 16 ...

Estefanía Álvarez Menéndez

acontezca la reiteración que nuestro Alto Tribunal exige a los efectos de entender establecida la jurisprudencia. Claro que la búsqueda de un segundo pronunciamiento a los solos efectos de reiteración no parece que sea lo más satisfactorio para lograr la eficacia del modelo ni tampoco parece conveniente admitir el recurso de casación autonómico a los efectos de reiterar el pronunciamiento emitido en la instancia, pues el establecimiento de la jurisprudencia «menor» sería, si se nos permite, un tanto artificioso.

No obstante, el panorama no está tan despejado como pudiera parecer ni pueden descartarse rotundamente los posicionamientos adoptados por nuestros Tribunales Superiores de Justicia porque el Tribunal Supremo se ha apartado en numerosas ocasiones de su postura mayoritaria y ha admitido el recurso, pese a la existencia de jurisprudencia, a los efectos de depurar contradicciones con la misma.

Recientemente, nuestro Alto Tribunal se ha mostrado partidario de admitir el recurso de casación si la sentencia de instancia se aparta de su jurisprudencia aun cuando esta ya se encuentre establecida. Así, en el ATS de 12 de diciembre de 2018 (Sala de lo Contencioso-Administrativo, Sección 1. ${ }^{\text {a) }}$ (núm. Rec. 5848/2018) (JUR 2018/330101) se señala que la «cuestión jurídica enunciada ha sido resuelta por la Sección Segunda de esta Sala de lo Contencioso-Administrativo del Tribunal Supremo en sus sentencias de 23 de mayo de 2018 (RCA/1880/2017; ES:TS:2018:2185 y 4202/2017; ES:TS:2018:2186), en el sentido que aquí defiende la parte recurrente, lo que también justifica la admisión del presente recurso de casación» ${ }^{15}$.

Y no solo admite, sino que parece defender que la contradicción con la jurisprudencia sería una razón de peso que justificaría la admisión del recurso. Ahora bien, estas afirmaciones han de realizarse con suma cautela puesto que pudiera haber quien defendiese que se trata de una resolución aislada y que la admisión tendría su razón de ser en el posible desconocimiento de la jurisprudencia por el órgano de instancia ${ }^{16}$. Si examinamos la sentencia recurrida esta habría sido dictada poco antes que las sentencias del Tribunal Supremo que establecen la jurisprudencia al respecto, en concreto la sentencia de instancia era de fecha 19 de junio de 2018.

Si estamos ante un giro definitivo en la doctrina o ante un episodio aislado es algo que solo podrá confirmar el paso del tiempo, pero lo que sí estamos en disposición de afirmar es que han sido numerosas las excepciones a su doctrina general que han llevado al Tribunal Supremo a admitir, en ocasiones, el recurso pese a la existencia de jurisprudencia previa. $\mathrm{E}$, incluso, por concurrencia del supuesto de interés casacional previsto en el artículo 88.2. a) LJCA -fijar, ante cuestiones sustancialmente iguales, una interpretación de las normas de derecho estatal o de la Unión Europea en las que se fundamenta el fallo contradictoria con la que otros órganos jurisdiccionales hayan establecido-, al haberse apartado la sentencia de instancia de la doctrina de nuestro Alto Tribunal ${ }^{17}$.

Asimismo, no es inusual encontrarnos con pronunciamientos como el del ATS de 28 de noviembre de 2018 (Sala de lo Contencioso-Administrativo, Sección 1. ${ }^{a}$ ) (núm. Rec. 4634/2018) (JUR 2018/325557), que ponen de manifiesto la posibilidad de admitir el recurso a los efectos de reafirmar o reforzar la jurisprudencia. La necesidad de reafirmar o reforzar es un argumento muy laxo que podría utilizar el Tribunal Supremo, pero también los Tribunales Superiores de Justicia, a los efectos de justificar la admisión del recurso pese a la existencia de jurisprudencia previa sobre la cuestión.

15 En el mismo sentido, vid. el ATS de 28 de noviembre de 2018 (Sala de lo Contencioso-Administrativo, Sección 1.a) (núm. Rec. 5724/2018) (JUR 2018/325357); así como el ATS de 14 de noviembre de 2018 (Sala de lo Contencioso-Administrativo, Sección 1. a) (núm. Rec. 4489/2018) (JUR 2018/327160), cierto es que en este último caso solo había recaído un pronunciamiento previo sobre la cuestión.

${ }^{16}$ Este argumento sobre el desconocimiento por el órgano de instancia de la jurisprudencia existente a efectos de admitir el recurso de casación se ha manejado, entre otros, en el ATS de 5 de junio de 2017 (Sala de lo Contencioso-Administrativo, Sección 1. ${ }^{a}$ ) (núm. Rec. 1098/2017) (JUR 2017/148949). Del mismo modo, para sortear el obstáculo de admitir el recurso cuando hay jurisprudencia previa, se ha aludido también al hecho de que el órgano de instancia pudo conocer, pero quizás no valorar adecuadamente la misma, vid. ATS de 7 de junio de 2017 (Sala de lo Contencioso-Administrativo, Sección 1. a) (núm. Rec. 1086/2017) (JUR 2017/143050).

17 Al respecto, vid., entre otros, el ATS de 22 de febrero de 2017 (Sala de lo Contencioso-Administrativo, Sección 1. ${ }^{a}$ ) (núm. Rec. 170/2016) (JUR 2017/47294) y el ATS de 12 de junio de 2017 (Sala de lo Contencioso-Administrativo, Sección 1.a) (núm. Rec. 1548/2017) (JUR 2017/157090). No obstante, la existencia de jurisprudencia previa y contradictoria con la dictada por el órgano de instancia no es garantía absoluta de admisión del recurso. Ha habido algún pronunciamiento del Tribunal Supremo que, interpretando fielmente el mandato legislativo, ha inadmitido el recurso pese a la contradicción con su jurisprudencia, precisamente porque se encontraba establecida y el interés casacional objetivo ha de serlo para la formación de jurisprudencia. En este sentido, vid. el ATS de 23 de mayo de 2018 (Sala de lo Contencioso-Administrativo, Sección 1. a) (núm. Rec. 527/2018) (JUR 2018/154577) que señala lo siguiente: «si la jurisprudencia está formada, tal y como mantiene la mercantil recurrente, el interés casacional objetivo del recurso preparado en esta concreta cuestión sólo existiría si fuera necesario matizarla, precisarla o concretarla para realidades jurídicas diferentes a las ya contempladas en esa jurisprudencia... sin que la parte recurrente haya argumentado suficientemente que nos encontramos ante un supuesto que pueda exigir un pronunciamiento distinto por parte de esta Sala». 
En vista de las oscilaciones doctrinales experimentadas en el seno de nuestro Alto Tribunal, no parece que quepa enjuiciar con excesiva rigidez los respectivos posicionamientos de los Tribunales Superiores de Justicia respecto a la admisión de la casación autonómica frente a sus propias sentencias. Puede que la finalidad del recurso de casación siga siendo la gran desconocida o puede que se conozca perfectamente que el recurso tal y como está ideado legislativamente se orienta a la «formación de jurisprudencia» pero al mismo tiempo se tenga presente que no solo interesa establecer jurisprudencia sino también defenderla, máxime si en nuestro sistema no es vinculante y los órganos jurisdiccionales pueden separarse de ella con la consiguiente fundamentación en derecho.

Es loable que el Tribunal Supremo trate de dar respuesta a la contradicción de la jurisprudencia sin supeditar la misma al establecimiento de doctrina, aunque quizás no fuese esa la intención del legislador al hacer depender la admisión del interés casacional objetivo «para la formación de jurisprudencia».

Ese malabarismo que el Tribunal Supremo se ve obligado a hacer para conciliar la redacción estricta de la ley y las necesidades que se suscitan en la práctica supone que los interrogantes en torno a la finalidad de este recurso no se despejen completamente y que los Tribunales Superiores de Justicia sigan sin tener claro si el recurso debe admitirse a los solos efectos de establecer jurisprudencia.

\section{EL ENJUICIAMIENTO CONSTITUCIONAL DE LA CASACIÓN AUTONÓMICA}

\subsection{El ATC de 16 de abril de 2018: La casación autonómica en Tribunales Superiores de Justicia de Sala y Sección única}

\subsubsection{Razones para una inadmisión de plano}

El panorama anteriormente expuesto, lejos de esclarecerse, se ensombrece más tras el Auto del Tribunal Constitucional de 16 de abril de 2018 (Pleno) (núm. Rec. 4644/2017) (RTC 2018/41 AUTO) que avala la postura adoptada por determinados Tribunales Superiores de Justicia, de Sala y Sección Única, de no reconocer el recurso de casación autonómico en sus respectivos ámbitos jurisdiccionales.

EI ATC de 16 de abril de 2018 inadmite un recurso de amparo preparado frente a un Auto del Tribunal Superior de Justicia de Extremadura que inadmite un recurso de casación autonómico frente a una sentencia del propio Tribunal. Igualmente, se preparó dicho recurso de amparo frente a la providencia por la que se inadmite el incidente de nulidad de actuaciones promovido frente a dicho Auto.

Las razones que ofrece el Tribunal Superior de Justicia para inadmitir el recurso de casación son de diversa índole. Así, ofrece motivos de carácter organizativo, pero también de incumplimiento de la finalidad que el recurso tiene encomendada. Incluso, se niega la operatividad del recurso en su ámbito jurisdiccional dados los términos en que se encuentra regulado.

En concreto, reflexiona dicho Tribunal Superior sobre la posibilidad de que el artículo 86.3 LJCA tenga como único cometido delimitar el ámbito de conocimiento del Tribunal Supremo. Es decir, que su único propósito sea impedir que nuestro Alto Tribunal se pronuncie sobre cuestiones de derecho autonómico.

Según su parecer, esta conclusión se ve reforzada por el hecho de que no exista precepto alguno que se ocupe de regular la tramitación de la casación autonómica. Claro que, en nuestra opinión, ello llevaría a negar el recurso de casación autonómico no solo frente a las sentencias del Tribunal Superior de Justicia sino también frente a las sentencias de los propios Juzgados de lo Contencioso-Administrativo, aunque en el caso de autos solo se enjuicia la inadmisión del recurso frente a sentencias del propio Tribunal.

No es el único razonamiento que ofrece para la inadmisión del recurso; también señala que su Sala de lo Contencioso-Administrativo culmina la organización jurisdiccional en su ámbito, sin que se haya previsto en la LOPJ la competencia de los Tribunales Superiores de Justicia para conocer de los recursos de casación autonómicos. En efecto, estos preceptos siguen aludiendo a la competencia de estos Tribunales para conocer del recurso de casación para la unificación de doctrina y en interés de ley autonómico. Tras un amplio periodo de vacatio legis y la entrada en vigor del nuevo recurso en julio de 2016, siguen sin depurarse estas cuestiones que no son en absoluto menores.

Continúa el Tribunal Superior de Justicia de Extremadura argumentando que la función de su Sala de lo Contencioso-Administrativo es establecer doctrina, y esta se realiza con el pronunciamiento en la instancia sobre la cuestión. A su juicio, al igual que no se ha previsto un recurso de casación frente a las sentencias del Tribunal Supremo tampoco tiene sentido que se prevea un recurso de casación autonómico frente a las 
REALA. Nueva Época - N. ${ }^{11}$, Abril-Septiembre 2019 - ISSN: 1989-8975 - DOI: 10.24965/reala.v0i11.10660 - [Págs. 75-95]

La disparidad de criterios interpretativos en torno a la casación autonómica y su enjuiciamiento constitucional en el ATC de 16 ...

Estefanía Álvarez Menéndez

sentencias del propio Tribunal Superior de Justicia. Aunque no ahonda más en este aspecto, veremos cómo el Tribunal Constitucional lo sitúa en el epicentro de su razonamiento a efectos de convalidar las tesis de citado Tribunal Superior de Justicia.

Mayor esfuerzo dedica el Tribunal Superior de Justicia de Extremadura a la hora de explicar que la Sección Casacional que se prevé en el artículo 86.3 LJCA es de imposible constitución en su ámbito jurisdiccional, dada la escasez de medios personales. En la medida en que su Sala de lo Contencioso-Administrativo se compone de cinco miembros, los mismos que se exigen para conformar la Sección Casacional, no quedaría más remedio que acudir a otras Salas del Tribunal Superior de Justicia o a Magistrados destinados en los Juzgados de lo Contencioso-Administrativo para componer la Sección Casacional, si se quiere evitar la contaminación de sus miembros. De llegar a producirse esa situación, sostiene el Tribunal Superior de Justicia que se vulneraría, entre otros, el derecho constitucional al juez predeterminado por la ley, pues esas otras Salas y Magistrados de los Juzgados de lo Contencioso-Administrativo no pueden desarrollar la competencia de la Sala de lo Contencioso-Administrativo.

Culmina su argumentación con una idea que está empezando a vislumbrarse en otros Tribunales Superiores de Justicia, aunque solo sea a través de Votos Particulares. Según su parecer, el recurso de casación autonómico solo está pensado para Tribunales Superiores de Justicia que dispongan de varias Salas de lo Contencioso-Administrativo o de varias Secciones dentro de una misma Sala ${ }^{18}$.

En atención a lo anteriormente razonado, el Tribunal Superior de Justicia inadmitió de plano el recurso de casación autonómico sin examinar la posible concurrencia de interés casacional objetivo para la formación de jurisprudencia y el recurrente consideró que se había infringido el derecho a la tutela judicial efectiva, en su vertiente de acceso a los recursos establecidos legalmente (artículo 24.1 CE), el derecho a la tutela judicial efectiva, sin que, en ningún caso, se produzca indefensión (artículo 24.1 CE) y el principio de igualdad en aplicación de la ley (artículo $14 \mathrm{CE}$ ), habida cuenta de las posturas favorables de otros Tribunales Superiores de Justicia a la admisión del recurso de casación autonómico frente a sus propias sentencias.

\subsubsection{Una inadmisión razonable según nuestro Tribunal Constitucional}

Antes de adentrarse en la apreciación de las eventuales infracciones a las que acabamos de hacer mención, el Tribunal Constitucional se afana en corregir una de las premisas de la que parte el recurrente: no se ha negado el derecho a un recurso previsto legalmente, sino que el Tribunal Superior de Justicia de Extremadura ha entendido que el mismo no es viable con arreglo a las leyes, dadas las particulares circunstancias de su ámbito jurisdiccional. La línea divisoria que pretende trazar el Tribunal Constitucional entre la negación del derecho al recurso previsto legalmente, que traería consigo una admisión del recurso de amparo por contravención del derecho a la tutela judicial efectiva, y la negación del derecho por su inviabilidad con arreglo a la ley, se presta, desde luego, a discusión.

Aclarada la premisa sobre la que ha de partir el enjuiciamiento constitucional, descarta nuestro Tribunal Constitucional la indefensión que se hace valer por el recurrente al haberse inadmitido de plano el recurso, sin que se haya valorado la concurrencia de interés casacional objetivo para la formación de jurisprudencia.

Entiende nuestro órgano constitucional que, si el recurso era improcedente, por los motivos que más adelante se expondrán, no resultaba necesario valorar la concurrencia del concepto jurídico indeterminado del que se hace depender la admisión del recurso.

Igualmente, descarta la infracción del principio de igualdad en la aplicación de la ley por el hecho de que otros Tribunales Superiores de Justicia hayan podido llegar a conclusiones distintas. No se cumple el requisito de identidad de órgano que el Tribunal Constitucional ha exigido tradicionalmente a los efectos de apreciar dicha infracción ${ }^{19}$.

18 Este argumento se maneja también en el Voto Particular formulado por la Magistrada PENÍN ALEGRE, C., al ATSJ de Cantabria de 6 de febrero de 2018 (Sala de lo Contencioso-Administrativo, Sección 1. ${ }^{a}$ ) (núm. Rec. 263/2017) (JUR 2018/59895), así como en el formulado por la Magistrada CASTANEDO GARCÍA, M. E., al ATSJ de Cantabria de 9 de mayo de 2018 (Sala de lo ContenciosoAdministrativo, Sección 1. ${ }^{a}$ ) (núm. Rec. 257/2017) (JUR 2018/160257).

19 Acerca de la eventual infracción del principio de igualdad en la aplicación de la ley, puede consultarse la STC de 28 de marzo de 2011 (núm. Rec. 9167/2008) (RTC 2011/38) que reproduce la doctrina emanada hasta el momento. Señala esta que «según reiterada doctrina de este Tribunal (entre otras muchas, SSTC 111/2002, de 6 de mayo [RTC 2002, 111], F. 2; 31/2008, de 25 de febrero [RTC 2008, 31], F. 2; 160/2008, de 12 de diciembre [RTC 2008, 160], F. 3; y 105/2009, de 4 de mayo [RTC 2009, 105], F. 5), para que pueda entenderse vulnerado este derecho, es necesaria la concurrencia de los siguientes requisitos: 
No obstante, lo que realmente interesa a nuestro estudio, es la eventual infracción del derecho a la tutela judicial efectiva en la vertiente de acceso a los recursos, al haberse inadmitido de plano el recurso de casación autonómico por el Tribunal Superior de Justicia de Extremadura.

En este Auto el Tribunal Constitucional reproduce su doctrina tradicional, conforme a la cual el derecho de acceso a los recursos es un derecho de configuración legal que se incorpora al derecho a la tutela judicial efectiva en la configuración que reciba de las leyes procesales. $Y$ ello, porque no nace directamente de la Constitución, a diferencia del derecho de acceso a la jurisdicción.

Asimismo, recuerda que la interpretación de la legalidad ordinaria corresponde a la jurisdicción ordinaria, siendo labor del Tribunal Constitucional la de efectuar un control meramente externo que no puede extenderse al juicio de proporcionalidad inherente al principio pro actione. Únicamente le corresponderá examinar si la inadmisión responde a una causa legalmente existente o si esta descansa sobre un juicio arbitrario, irrazonable o que incurre en error patente ${ }^{20}$.

Esta doctrina tradicional ha sido férreamente aplicada hasta el momento. Basta recordar que su aplicación estricta le ha llevado a convalidar requisitos procesales impuestos jurisprudencialmente sin sustento legal. Así sucedió cuando convalidó la interpretación adoptada por el Tribunal Supremo respecto al escrito de preparación del anterior recurso de casación. Nuestro Alto Tribunal exigía concretar los preceptos o jurisprudencia que se reputasen infringidos sin que dicho requisito fuese impuesto por el artículo 89.1 LJCA y aun así el Tribunal Constitucional consideró que dicha exigencia entraba «en el ámbito de la interpretación jurisprudencial de los requisitos para acceder al recurso de casación» ${ }^{21}$.

Pues bien, esta ocasión tampoco iba a ser una excepción. El Tribunal Constitucional se limita a examinar si la conclusión alcanzada por el Tribunal Superior de Justicia de Extremadura es razonable. A pesar de la magnitud de la decisión, Ilama la atención que el Tribunal Constitucional despache la cuestión en un único párrafo que no hace más que añadir incertidumbre al futuro de la casación autonómica.

Por su importancia, interesa que lo reproduzcamos íntegramente: «Con independencia del mayor o menor acierto de cada uno de los argumentos empleados en la resolución impugnada, valoración que nos está vedada en esta sede constitucional, la Sala de lo Contencioso-Administrativo toma como puntos de partida

a) La acreditación de un tertium comparationis, puesto que el juicio de igualdad sólo puede realizarse sobre la comparación entre la Sentencia impugnada y las precedentes resoluciones del mismo órgano judicial, que en casos sustancialmente iguales hayan sido resueltos de forma contradictoria.

b) La identidad de órgano judicial, entendiendo por tal, no sólo la identidad de Sala, sino también la de la Sección, al considerarse cada una de éstas como órgano jurisdiccional con entidad diferenciada suficiente para desvirtuar una supuesta desigualdad en la aplicación de la Ley. Esta exigencia permite valorar si la divergencia de criterio expresada por el juzgador es fruto de la libertad de apreciación del órgano jurisdiccional en el ejercicio de su función juzgadora (art. 117.3 CE [RCL 1978, 2836] ) y consecuencia de una diferente apreciación jurídica de los supuestos sometidos a su decisión, o, por el contrario, un cambio de valoración del caso puramente arbitrario, carente de fundamentación suficiente y razonable.

c) La existencia de alteridad en los supuestos contrastados, es decir, de "la referencia a otro" exigible en todo alegato de discriminación en aplicación de la Ley, excluyente de la comparación consigo mismo.

d) La ausencia de toda motivación que justifique en términos generalizables el cambio de criterio, bien lo sea para separarse de una línea doctrinal previa y consolidada, bien lo sea con quiebra de un antecedente inmediato en el tiempo y exactamente igual desde la perspectiva jurídica con la que se enjuició. La razón de esta exigencia estriba en que el derecho a la igualdad en la aplicación de la Ley, en conexión con el principio de interdicción de la arbitrariedad (art. 9.3 CE), obliga a que un mismo órgano jurisdiccional no pueda cambiar caprichosamente el sentido de sus decisiones adoptadas con anterioridad en casos sustancialmente iguales sin una argumentación razonada de dicha separación que justifique que la solución dada al caso responde a una interpretación abstracta y general de la norma aplicable y no a una respuesta ad personam, singularizada. Lo que negativamente significa que no podrá apreciarse la lesión de este derecho fundamental cuando el cambio de criterio responda a una vocación de generalidad, ya sea porque en la resolución se explicitan las razones que lo motivan o porque así se deduzca de otros elementos de juicio externos, como pueden ser significativamente posteriores pronunciamientos coincidentes con la línea abierta en la Sentencia impugnada, que permitan apreciar dicho cambio como solución genérica aplicable en casos futuros y no como fruto de un mero voluntarismo selectivo frente a casos anteriores resueltos de modo diverso (STC 184/2007, de 10 de septiembre [RTC 2007, 184], F. 2)».

20 Puede consultarse, entre otras, la STC de 17 de octubre de 2016 (Sala Primera) (núm. Rec. 3143/2013) (RTC 2016/173) que sintetiza dicha doctrina constitucional en los siguientes términos: «este Tribunal ha venido reiterando que la interpretación y aplicación de las normas procesales que contemplan los requisitos para la admisión de los recursos son materias de legalidad ordinaria, propias de los Tribunales de Justicia (art. 117.3 CE (RCL 1978, 2836) ), de modo que el control de las resoluciones judiciales de inadmisión de los recursos por parte de la jurisdicción constitucional "es meramente externo" y debe limitarse a comprobar si, además de tener motivación, "han incurrido en error material patente, en arbitrariedad o en manifiesta irrazonabilidad lógica, evitando toda ponderación acerca de la corrección jurídica de las mismas" y "sin que el control que nos corresponde realizar... pueda extenderse al juicio de proporcionalidad inherente al principio pro actione , característico del derecho de acceso a la jurisdicción" (por todas, SSTC 258/2000, de 30 de octubre (RTC 2000, 258), FJ 2; 42/2009, de 9 de febrero (RTC 2009, 42), FJ 2; 65/2011, de 16 de mayo (RTC 2011, 65), FJ 3, y 142/2015, de 22 de junio (RTC 2015, 142), FJ 3)».

21 Al respecto, vid. STC de 22 de enero de 2015 (Pleno) (núm. Rec. 2399/2012) (RTC 2015/7). 
REALA. Nueva Época - N. ${ }^{11}$, Abril-Septiembre 2019 - ISSN: 1989-8975 - DOI: 10.24965/reala.v0i11.10660 - [Págs. 75-95]

La disparidad de criterios interpretativos en torno a la casación autonómica y su enjuiciamiento constitucional en el ATC de 16 ...

Estefanía Álvarez Menéndez

unos presupuestos certeros y llega a la solución que ofrece mediante una argumentación lógica y coherente. Parte este discurso de la literalidad de los preceptos legales referidos al recurso de que se trata en la Ley reguladora de la jurisdicción contencioso-administrativa y la Ley Orgánica del Poder Judicial (RCL 1985, 1578, 2635); toma en consideración, a continuación, la composición y posición institucional de la Sala sentenciadora y del órgano que estaría llamado a resolver el recurso; y constata, derivado de ello, que la finalidad a que estaría llamado este eventual recurso de casación, cual es la de asegurar la uniformidad en la interpretación y aplicación del ordenamiento jurídico autonómico, en las circunstancias expresadas, quedó ya satisfecha en la Sentencia dictada por el Pleno de esa Sala de lo Contencioso-Administrativo. En este razonamiento mantenido por el Auto impugnado no se apela a razones organizativas para justificar la inadmisión del recurso, sino que se considera que el recurso de casación autonómico, en el caso, al no resultar idóneo para cumplir la función inherente a su naturaleza, carece de razón de ser. A partir de aquí, la Sala obtiene la conclusión, que se apoya también en el tenor literal del artículo 86.3 LJCA, de que este recurso «está pensado para los casos de un Tribunal Superior de Justicia que dispone de varias Salas de lo Contencioso-Administrativo o de varias Secciones dentro de la misma Sala».

Según nuestro Tribunal Constitucional, la interpretación que efectúa el Tribunal Superior es razonable porque la inadmisión descansa en la inidoneidad del recurso para cumplir la finalidad que es propia de un recurso de casación. Cabe pensar que este razonamiento obedece a lo manifestado por el Tribunal Superior de Justicia de Extremadura acerca de que la finalidad del recurso se satisface con el propio pronunciamiento de instancia que ya establece doctrina sobre la cuestión.

Se afana el Tribunal Constitucional en aclarar que no han sido causas de tipo organizativo las que han llevado a tomar la decisión de inadmisión, cuando esta cuestión no se desprende con claridad meridiana de los razonamientos ofrecidos por el Tribunal Superior de Justicia. Y, además, cabe dudar de que realmente estas no hayan sido decisivas, pues el Tribunal Superior de Justicia de Extremadura sí considera que el recurso de casación autonómico cabe en el supuesto de que los Tribunales Superiores de Justicia cuenten con varias Salas o Secciones dentro de una Sala.

Si la clave de la inadmisión reside en la inidoneidad del recurso para cumplir con la finalidad que tiene encomendada, igual de inidóneo sería el recurso en Tribunales Superiores de Justicia de varias Salas o Secciones que en los de única Sala y Sección, pues en todos ellos la jurisprudencia se encuentra establecida por el pronunciamiento de instancia.

El Tribunal Constitucional considera que es producto de una exégesis racional el hecho de que el Tribunal Superior de Justicia de Extremadura sostenga que el recurso de casación autonómico solo cabe en los ámbitos jurisdiccionales de Tribunales Superiores de Justicia con varias Salas o varias Secciones dentro de una misma Sala.

En nuestra opinión, este razonamiento que esgrime el Tribunal Superior de Justicia de Extremadura podría ir, incluso, en contra del propio texto legal que, a diferencia de lo que sucedía bajo la vigencia del recurso de casación autonómico en unificación de doctrina, no hace distinciones entre aquellos Tribunales Superiores de Justicia que disponen de varias Salas y Secciones y aquellos que únicamente cuenta con una Sala y Sección ${ }^{22}$. Es decir, no se excluye expresamente la conformación de dicha Sección Casacional en Tribunales Superiores de Justicia de única Sala y Sección ${ }^{23}$.

El propio artículo 86.3 LJCA contiene reglas especiales a efectos de constituir dicha Sección «si la Sala o Salas de lo Contencioso-Administrativo tuviesen más de una Sección», lo que nos lleva a pensar que no necesariamente han de contar con más de una Sala y Sección para que se constituya aquella. Además, debe tenerse en cuenta que si se reconociese que el recurso solo se encuentra operativo en Tribunales Superiores de Justicia que dispongan de varias Salas de lo Contencioso-Administrativo y/o varias Secciones, quedarían también fuera del control casacional, en los Tribunales Superiores de Justicia de única Sala y

22 Al respecto, ALONSO MURILLO, F., señala que «el contenido de estos dos preceptos reproduce miméticamente en este particular el derogado artículo 99.3 LJCA, compartiendo lógicamente sus mismos defectos, a los que se añaden los que derivan de la nueva configuración del recurso de casación autonómico que, a diferencia del fenecido recurso de casación para la unificación de doctrina autonómico, no se imposibilita legalmente cuando en el Tribunal Superior de Justicia no cuente más que con una Sección en su única Sala de lo Contencioso-administrativo, lo que convierte este recurso extraordinario en tales casos en una suerte de recurso de reposición...», vid. "El nuevo recurso de casación contencioso-administrativo en materia tributaria", op. cit., págs. 140-141.

${ }^{23}$ En sentido contrario, hay autores que consideran que en supuestos de Sala y Sección Única, no sería necesario constituir la Sección Casacional sino que el conocimiento del recurso se atribuiría a la propia Sala y Sección de enjuiciamiento, vid. SOSPEDRA NAVAS, F. J. (2017): "El controvertido ámbito de las resoluciones recurribles en el recurso de casación contencioso-administrativo", en Revista Aranzadi Doctrinal, núm. 3, Aranzadi, pág. 8. 
REALA. Nueva Época - N. ${ }^{11}$, Abril-Septiembre 2019 - ISSN: 1989-8975 - DOI: 10.24965/reala.v0i11.10660 - [Págs. 75-95]

La disparidad de criterios interpretativos en torno a la casación autonómica y su enjuiciamiento constitucional en el ATC de 16 ...

Estefanía Álvarez Menéndez

Sección, las sentencias de los Juzgados de lo Contencioso-Administrativo, que no plantean problemas de contaminación ni de incumplimiento de la finalidad asignada al recurso de casación.

Al margen de este paréntesis que hemos abierto, prosigue el Tribunal Constitucional su razonamiento y señala que la solución del Tribunal Superior de Justicia de Extremadura que aquí se ha considerado razonable «no obsta a que, en el marco de las incertidumbres que ha ocasionado la regulación de la casación autonómica tras la Ley Orgánica 7/2015, de 21 de julio, otras interpretaciones judiciales dirigidas a darles respuesta puedan a su vez ser perfectamente razonables».

Este último párrafo nos genera numerosas inquietudes. Cabe preguntarse si sería razonable que Tribunales Superiores de Justicia de única Sala y Sección pudieran llegar a soluciones contrarias y defender el recurso de casación autonómico frente a sus propias sentencias. Es decir, si puede ser razonable una tesis y su contraria y, ciertamente, no nos parece defendible.

Asimismo, si la improcedencia del recurso se debe al incumplimiento de la finalidad que le corresponde al recurso de casación, entendiendo por tal la «formación de jurisprudencia», cabe preguntarse si sería razonable que se admitiese el recurso de casación autonómico en los Tribunales Superiores de Justicia con varias Salas o varias Secciones dentro de una misma Sala. Consideramos que en estos casos la finalidad es igualmente irrealizable pues ya se habrá establecido en la instancia, dejando a salvo las admisiones a los efectos de reiteración de la jurisprudencia y las admisiones para matizar o precisar, según la jurisprudencia del Tribunal Supremo, que también podrían acontecer en Tribunales Superiores de Justicia de única Sala y Sección.

Llevada al extremo la tesis de nuestro Tribunal Constitucional y sobre la base de la improcedencia por incumplimiento de la finalidad asignada, cualquier Tribunal Superior de Justicia podría defender la inadmisión del recurso sin que su razonamiento pudiera tacharse de irrazonable a la vista de este pronunciamiento.

Nuevamente, nos encontramos con que la finalidad del recurso de casación debe constituirse en el criterio interpretativo decisivo para la admisión de estos recursos. Si nos atenemos al texto legal, las resoluciones de los Tribunales Superiores de Justicia son potencialmente recurribles en casación autonómica, la inadmisión de plano no debiera tener cabida y debiera examinarse en cada caso la concurrencia de posible interés casacional objetivo para la formación de jurisprudencia. Ahora bien, como hemos dejado expuesto, no puede negarse que este difícilmente concurrirá si se interpreta que el interés casacional objetivo ha de serlo para la formación de jurisprudencia, al encontrarse esta establecida en la instancia.

\subsection{La STC de 29 de noviembre de 2018: la consagración de la casación autonómica y la convalidación de sus defectos}

El Tribunal Constitucional disponía de una nueva oportunidad para acabar con la disparidad interpretativa al hilo de la resolución de las cuestiones de inconstitucionalidad que, sobre el recurso de casación autonómico, el Tribunal Superior de Justicia de Castilla-La Mancha había sometido a su consideración. Sin embargo, su Sentencia de 29 de noviembre de 2018 (Pleno) (Cuestión de inconstitucionalidad núm. 2860/2018) (RTC 2018/128) tampoco despeja el panorama interpretativo al convalidar, sin unanimidad en su seno, la formulación legal del citado medio impugnatorio sobre la base de que este recurso está pensando para ser articulado en Tribunales Superiores de Justicia que dispongan de varias Salas y/o Secciones.

\subsubsection{Una regulación respetuosa con la reserva de ley orgánica prevista en el artículo 122 CE}

La cuestión de inconstitucionalidad planteada por el citado Tribunal Superior de Justicia se articulaba en torno a cuatro motivos. El primero de ellos se sustentaba en la posible inconstitucionalidad del recurso de casación autonómico al haberse regulado por ley ordinaria ${ }^{24}$ y entrañar ello una vulneración de la reserva de ley orgánica prevista en el artículo $122 \mathrm{CE}$, que se encuentra redactado en los siguientes términos: "La ley orgánica del poder judicial determinará la constitución, funcionamiento y gobierno de los Juzgados y Tribunales, así como el estatuto jurídico de los Jueces y Magistrados de carrera, que formarán un Cuerpo único, y del personal al servicio de la Administración de Justicia».

24 La nueva regulación casacional fue fruto de la modificación de la Ley reguladora de la Jurisdicción Contencioso-Administrativa operada por la Disposición Final Tercera de la LO 7/2015, de 21 de julio y la Disposición Final Quinta de la citada Ley Orgánica señala que la citada Disposición Final Tercera tiene carácter de ley ordinaria. 
Según el Tribunal Superior de Justicia de Castilla-La Mancha, a la novedad del órgano encargado de resolver el recurso de casación autonómico habría que sumar el hecho de que el precepto regulador del recurso no llenase de contenido la idea del ámbito de conocimiento litigioso, manejada por el Tribunal Constitucional a la hora de interpretar el artículo $122 \mathrm{CE}$. A su juicio, existen dudas fundadas sobre las resoluciones recurribles y sobre los supuestos de interés casacional objetivo que cabe invocar, sin que quepa acudir a la aplicación analógica en el caso de normas procesales.

El Tribunal Constitucional descarta dicha tacha de constitucionalidad haciendo acopio de la doctrina constitucional sobre la reserva contenida en dicho precepto, que tantas dudas suscita en la práctica. Así, recuerda que el término "constitución de los Juzgados y Tribunales», empleado en el artículo $122 \mathrm{CE}$, debe comprender, como mínimo, «la institución de los diferentes órdenes jurisdiccionales y la definición genérica de su ámbito de conocimiento litigioso». No obstante, «cabe que el legislador ordinario concrete las materias específicas objeto del conocimiento de tales órdenes», sin contradecir el diseño que haya realizado la ley orgánica de los distintos órganos jurisdiccionales. En otras palabras, «no toda materia debe estar residenciada en la Ley Orgánica del Poder Judicial... La Ley Orgánica del Poder Judicial establece los criterios generales de atribución y las leyes ordinarias concretan esos criterios en cada ámbito específico» ${ }^{25}$.

Aclara nuestro Órgano Constitucional que nunca han formado parte del contenido mínimo de la reserva cuestiones tales como las resoluciones recurribles o los órganos competentes para su resolución, así como tampoco el procedimiento que ha de seguirse en la tramitación.

Nos señala, así, el camino hacia el rechazo de la tacha planteada, pues el hecho de que las resoluciones recurribles y el órgano competente para conocer del recurso de casación autonómico se hayan regulado por ley ordinaria no supone vulneración alguna de la reserva contenida en el artículo 122 CE. De hecho, recuerda que dichos extremos tampoco se contenían antes en el artículo 74 LOPJ, apartados 5 y 6 , que hacían y hacen referencia, pues no se ha depurado dicho extremo, a los anteriores recursos de casación autonómicos en unificación de doctrina y en interés de ley.

No obstante, hace una matización a sus afirmaciones y señala que, si el órgano encargado de resolver el recurso fuese un órgano judicial nuevo, distinto a las Salas de lo Contencioso-Administrativo de los Tribunales Superiores de Justicia, la respuesta a la cuestión planteada variaría sustancialmente. De ser ese el caso, su institución por ley ordinaria supondría una vulneración de la reserva anteriormente comentada.

Así pues, dedica el Tribunal Constitucional buena parte de sus esfuerzos a desentrañar si estamos ante un órgano judicial distinto de las Salas mencionadas o si se trata meramente de una división funcional de dichas Salas. A su juicio, la Sección Casacional regulada en el artículo 86.3 LJCA es una Sección funcional $y$, por tanto, puede ser creada por ley ordinaria.

Según su criterio, dicha calificación se justifica fundamentalmente por la concurrencia de dos indicios: a) la composición del órgano no se ha establecido de forma reglada; b) los Magistrados que conforma la misma pertenecen al mismo orden jurisdiccional, cuando no a la misma Sala de lo Contencioso-Administrativo.

Esta conclusión acerca de que la Sección Casacional es una división funcional de la Sala de lo Contencioso-Administrativo de los Tribunales Superiores de Justicia, así como los indicios tomados para alcanzar la misma, no son compartidos por los Magistrados XIOL RÍOS y ENRÍQUEZ SANCHO, que formulan Votos Particulares a la Sentencia que aquí nos ocupa.

El primero de ellos sostiene que estamos ante una Sección orgánica y, por tanto, al tratarse de un nuevo órgano judicial debería haberse constituido por ley orgánica. Para sustentar su razonamiento señala que el Tribunal Constitucional parte de una premisa errónea al considerar que son Secciones funcionales en la medida en que la composición del órgano no se establece de forma reglada en el artículo 86.3 LJCA. Certeramente, señala XIOL RÍOS que dicho precepto sí establece la composición; cuestión distinta es que se confíe a la Sala de Gobierno de cada Tribunal Superior de Justicia, en el caso de que la Sala o Salas de lo Contencioso-Administrativo tengan más de una Sección, el turno con arreglo al cual los Magistrados ocuparán los puestos a los que hace mención la ley reguladora de la jurisdicción contencioso-administrativa.

Asimismo, considera que el hecho de que la Sección Casacional pueda conformarse con Magistrados de diversos órganos judiciales resulta determinante para considerar a dicha Sección como un órgano judicial nuevo. Según XIOL RÍOS, la clave para considerar a una Sección como división funcional no se encuentra

25 Sobre el alcance de la reserva de ley orgánica contenida en el artículo $122 \mathrm{CE}$, el Tribunal Constitucional nos remite a su doctrina tradicional prevista en STC de 1 de julio de 1993 (Pleno) (Cuestión de inconstitucionalidad núm. 5/1991 y 649/1991) (RTC 1993/224), STC de 21 de septiembre de 1994 (Pleno) (Cuestión de Inconstitucionalidad núm. 173/1993 y 1819/1992) (RTC 1994/254) y STC de 7 de julio de 2011 (Pleno) (Cuestión de Inconstitucionalidad núm. 10663/2006) (RTC 2011/121). 
REALA. Nueva Época - N. ${ }^{11}$, Abril-Septiembre 2019 - ISSN: 1989-8975 - DOI: 10.24965/reala.v0i11.10660 - [Págs. 75-95]

La disparidad de criterios interpretativos en torno a la casación autonómica y su enjuiciamiento constitucional en el ATC de 16 ...

Estefanía Álvarez Menéndez

en que los Magistrados pertenezcan al mismo orden jurisdiccional, sino en que pertenezcan al mismo órgano jurisdiccional.

De igual forma, siguiendo su razonamiento, el hecho de que dicha Sección Casacional tenga competencia propia y distinta de las Salas de lo Contencioso-Administrativo regulada en la ley, hace que nos encontremos ante un nuevo órgano jurisdiccional. Añade este Magistrado que, aun cuando pudieran considerarse como Secciones funcionales estas Secciones Casacionales -opinión que no comparte-, estas contravendrían la ordenación que de las mismas realiza la Ley Orgánica del Poder Judicial en sus artículos 152 y 198.

En la misma línea discurre el Voto Particular formulado por ENRÍQUEZ SANCHO, quien discrepa del parecer de la mayoría y considera que la constitución de la Sección Casacional vulnera la reserva de ley establecida en el artículo 122 CE. Según este Magistrado, al atribuírsele a esta Sección una competencia específica, excluyente y exclusiva, y regular la LJCA reglas exclusivas para su composición, sin que la Sala de Gobierno del Tribunal Superior pueda suprimirlas, crearlas o decidir libremente la composición, más allá de fijar los turnos, nos distanciamos de las notas propias de las Secciones funcionales creadas al amparo del artículo 72.2 LOPJ, con ruptura del sistema establecido por la Constitución y la LOPJ. A ello debe sumarse el hecho de que exista cierta prevalencia de la Sección Casacional sobre las Salas de lo ContenciosoAdministrativo, pues esta última puede ser enmendada por la primera.

Compartimos sus razonamientos y consideramos que el Tribunal Constitucional no solo parte de una premisa errónea al interpretar que la composición de la Sección Casacional no se ha establecido de forma reglada, sino que también lo hace cuando señala que la Sección Casacional estará constituida por Magistrados del mismo orden, en todo caso. Aunque, efectivamente, podría llegar a sostenerse si, como parece hacer el Tribunal Constitucional, se reconoce el recurso de casación autonómico únicamente en Tribunales Superiores de Justicia de varias Salas y/o Secciones, que no presenten problemas de medios personales.

La práctica demuestra que los Tribunales Superiores de Justicia de Sección única que han reconocido en su ámbito jurisdiccional el recurso de casación autonómico, han tenido que acudir a Magistrados de otros órdenes para evitar que tomen parte de la decisión los Magistrados que han decidido del asunto en la instancia. Es más, en algunos casos, la Sección Casacional ha quedado enteramente conformada por Magistrados pertenecientes a otros órdenes jurisdiccionales ${ }^{26}$.

Si siguiésemos este criterio del Tribunal Constitucional, deberíamos plantearnos si hay que considerar que estamos ante un órgano judicial nuevo, con la consiguiente vulneración de la reserva prevista en el artículo 122 CE, en todos aquellos Tribunales que han tenido que acudir a Magistrados de otros órdenes para conformar la Sección Casacional. O si, directamente estos no debieran admitir el recurso de casación en su ámbito jurisdiccional respectivo, pues parece que esta es la opción que el Tribunal Constitucional ve como razonable, aunque ya hemos dejado apuntado que el texto legal parece apuntar en otra dirección.

\subsubsection{La seguridad jurídica no se ve afectada y la disparidad interpretativa de nuestros Tribunales Superiores de Justicia no vulnera el artículo 14 CE}

La segunda duda de constitucionalidad planteada por el Tribunal Superior de Justicia de Castilla-La Mancha guarda relación con el principio de seguridad jurídica del artículo 9.3 CE. Se plantea si acaso no se produce dicha inseguridad jurídica cuando operadores jurídicos cualificados no son capaces de alcanzar

26 Por ofrecer un ejemplo, cabe citar la situación que acontece en el seno de la Sala de lo Contencioso-Administrativo del Tribunal Superior de Justicia de Cantabria. Este Sala, que funciona como única Sección, está integrada por cuatro Magistrados, uno en excedencia y dos adscritos de la Sala Civil y Penal. Si se pretende evitar la contaminación de sus Magistrados y conformar la Sección Casacional con cinco miembros, tal y como exige el artículo 86.3 LJCA, no quedará otra alternativa que integrar la misma con Magistrados pertenecientes a otros órdenes jurisdiccionales, separándonos también en este caso del mandato legislativo que exige la pertenencia al orden contencioso-administrativo. Esta circunstancia es puesta de relieve por los Votos Particulares formulados por PENÍN ALEGRE, C., y CASTANEDO GARCÍA, M. E., a los AATSJ de Cantabria anteriormente mencionados. En opinión de dichas Magistradas, podría entenderse vulnerado el derecho al juez predeterminado por la ley, a la vez que carece de toda lógica que una Sección integrada por no especialistas enmiende a una Sección cuyos miembros son especialistas.

Más llamativo es el caso de La Rioja, cuya Sala de lo Contencioso-Administrativo -Sección Única- está compuesta por tres Magistrados. Ni siquiera se alcanza el número mínimo de integrantes que exige el artículo 86.3 LJCA. Su petición de refuerzos para poner en funcionamiento la casación autonómica fue archivada, vid. Acta núm. 2/2018 de la reunión de la Sala de Gobierno del Tribunal Superior de Justicia de La Rioja celebrada el día 22 de febrero de 2018, dirección URL: http://www.poderjudicial.es/cgpj/es/PoderJudicial/Tribunales-Superiores-de-Justicia/TSJ-La-Rioja/Sala-de-Gobierno/Acuerdos-Sala-de-Gobierno/Acta-de-la-sesion-de-la-Salade-Gobierno-del-TSJ-de-La-Rioja-de-22-de-febrero-de-2018. Si se pretende evitar la contaminación de sus Magistrados, no quedará más remedio que acudir a Magistrados integrantes de otros órdenes jurisdiccionales. 
REALA. Nueva Época - N. ${ }^{11}$, Abril-Septiembre 2019 - ISSN: 1989-8975 - DOI: 10.24965/reala.v0i11.10660 - [Págs. 75-95]

La disparidad de criterios interpretativos en torno a la casación autonómica y su enjuiciamiento constitucional en el ATC de 16 ...

Estefanía Álvarez Menéndez

un acuerdo respecto a cuestiones trascendentales como son, entre otras, las resoluciones recurribles en casación autonómica.

El Tribunal Constitucional se pregunta si realmente esas deficiencias que pudiera plantear la regulación casacional impiden al Tribunal Superior de Justicia resolver sobre la admisión del recurso. Al considerar que no es así, entiende que ello constituye un claro indicio de que la inseguridad jurídica que se hace valer no es de gravedad.

Defiende nuestro Órgano constitucional que el hecho de que la redacción de una norma traiga consigo problemas interpretativos no obliga a considerar que se ha vulnerado el principio de seguridad jurídica. Al concebirse el ordenamiento como un todo, será necesario examinar si esas dudas interpretativas pueden despejarse teniendo en cuenta el contexto en que se insertan dichos preceptos.

En sus propias palabras, «sólo si, en el contexto ordinamental en que se inserta y teniendo en cuenta las reglas de interpretación admisibles en Derecho, el contenido o las omisiones de un texto normativo produjeran confusión o dudas que generaran en sus destinatarios una incertidumbre razonablemente insuperable acerca de la conducta exigible para su cumplimiento o sobre la previsibilidad de sus efectos, podría concluirse que la norma en cuestión infringe el principio de seguridad jurídica» ${ }^{27}$.

A su juicio, en esta ocasión no concurre un alto grado de indeterminación, pues las reglas que se prevén para la casación estatal se pueden aplicar mutatis mutandis a la casación autonómica. A lo que añade que «la indeterminación del precepto legal cuestionado no conlleva una quiebra de la seguridad jurídica, pues una interpretación sistemática del mismo permite acotar su sentido y determinar las resoluciones que pueden ser objeto de este recurso y el órgano que ha de resolverlo».

Realmente, se nos antoja difícil la aplicación de la normativa reguladora de la casación estatal en numerosos puntos. En la parte procedimental será difícil adecuarla si tenemos en cuenta que el conocimiento de la casación estatal se atribuye a un órgano jurisdiccional distinto del que dicta la sentencia de instancia, lo que no siempre sucede en la casación autonómica, y que se distingue entre una Sección de admisión y una Sección de enjuiciamiento, esquema que no se sigue como regla general en nuestros Tribunales Superiores de Justicia, dada la falta de medios personales.

Por ofrecer algún ejemplo, sería llamativo que se mantuviese la doble fase de preparación-interposición si se están recurriendo en casación autonómica las propias sentencias del Tribunal Superior de Justicia. Si el mantenimiento de esta bipartición es criticable en la casación estatal, carece aún más de sentido en el caso de que se recurran dichas resoluciones en casación autonómica.

Aun cuando pudiera forzarse su aplicación, ya hemos dejado apuntado antes que el recurso de casación estatal está orientado a la "formación de jurisprudencia». Si seguimos fielmente el mandato legislativo, difícilmente puede realizarse dicha finalidad si se recurren sentencias de los Tribunales Superiores de Justicia, pues la doctrina se ha establecido al conocer del litigio en la instancia.

La aplicación a la casación autonómica de la normativa relativa a la casación estatal no soluciona los problemas interpretativos. $\mathrm{O}$ al menos no todos los que se presentan, pues, a diferencia de lo que sostiene el Tribunal Constitucional, seguimos teniendo dudas razonables acerca de si los párrafos primero y segundo del artículo 86.3 LJCA son complementarios o independientes. Tal y como hemos dejado expuesto anteriormente, optar por una u otra solución supondría reconocer o no el recurso frente a las sentencias de los Juzgados de lo Contencioso-Administrativo, que debieran constituir el verdadero objeto de la casación autonómica.

El Tribunal Superior de Justicia de Castilla-La Mancha todavía plantea una tercera duda de constitucionalidad basada en una eventual infracción del principio de igualdad del artículo 14 CE, dada la disparidad interpretativa que existe entre nuestros Tribunales Superiores de Justicia al aplicar la casación autonómica.

El recorrido de esta invocación era fácil de adivinar si tenemos en cuenta la doctrina constitucional sobre dicho principio y el pronunciamiento del ATC de 16 de abril de 2018. Una vez más, el Tribunal Constitucional señala que la apreciación de dicha infracción exige que estemos en presencia del mismo órgano judicial, y no como sucede en este caso, en que las opiniones dispares provienen de Tribunales Superiores de Justicia distintos, quedando aquellas amparadas por la independencia judicial.

Recuerda dicho Tribunal que, siguiendo su doctrina tradicional, «la desigualdad o la discriminación que se prohíbe mediante el artículo $14 \mathrm{CE}$ es la que se origina en la función jurisdiccional de un mismo órgano judicial, al interpretar o aplicar de forma diversa una misma norma ante supuestos de hecho similares, no

${ }^{27}$ Igualmente, para conocer el parecer de nuestro Tribunal Constitucional sobre la infracción del principio de seguridad jurídica por deficiente redacción legislativa cabe citar la STC de 13 de septiembre de 2011 (Pleno) (núm. Rec.1390/1999) (RTC 2011/136), que sintetiza la doctrina al respecto. 
REALA. Nueva Época - N. ${ }^{11}$, Abril-Septiembre 2019 - ISSN: 1989-8975 - DOI: 10.24965/reala.v0i11.10660 - [Págs. 75-95]

La disparidad de criterios interpretativos en torno a la casación autonómica y su enjuiciamiento constitucional en el ATC de 16 ...

Estefanía Álvarez Menéndez

la que se produce por el hecho de que distintos órganos judiciales realicen una interpretación o aplicación distintas de la misma norma jurídica, pues la independencia judicial ampara la capacidad de cada Juez y Tribunal de seleccionar, interpretar y aplicar las normas que consideren relevantes para resolver el asunto de que conocen, siendo la razonabilidad el único parámetro de constitucionalidad que podría proyectarse sobre tales operaciones».

\subsubsection{El derecho al juez predeterminado por la ley y el artículo 24 CE permanecen incólumes}

La última duda de constitucionalidad se refiere a la infracción del derecho a la tutela judicial efectiva del artículo 24 CE. Para el Tribunal Superior de Justicia de Castilla-La Mancha, el artículo 86.3 LJCA enuncia el recurso de casación autonómico, pero no lo desarrolla, lo cual supone una afectación del citado derecho, tanto respecto al juez predeterminado por la ley como por el procedimiento considerado.

El Tribunal Constitucional descarta dicha tacha al entender que, aun cuando se hubiese previsto un recurso sin dotarlo de desarrollo legal, no quedaría afectado el derecho a la tutela judicial efectiva, sino que simplemente se aplazaría su efectividad hasta que se produzca aquel. No obstante, entiende dicho Tribunal que en este caso cabe acudir a las normas de la casación estatal y lograr así una interpretación lógica y coherente del artículo 86.3 LJCA.

También rechaza la eventual infracción del derecho al juez predeterminado por la ley, dado que se han creado y establecido por ley los criterios necesarios para determinar la composición del órgano judicial competente para resolver el recurso de casación autonómico, así como determinado su ámbito competencial (artículo 86.3 LJCA).

Afirma el Tribunal Constitucional que «no cabe duda de que el párrafo tercero del art. 86.3 LJCA tiene rango legal y que contiene los criterios necesarios para determinar la composición de la Sección de casación, tanto en el supuesto de las Salas que no tengan Sección como en el caso de que tengan más de una Sección». Cabe plantearse si, al realizar estas afirmaciones, está siendo congruente con lo proclamado al calificar a las Secciones de casación como divisiones funcionales, pues se apreciaba como indicio que «la composición de las referidas Secciones no ha sido establecida de forma reglada».

Asimismo, la afirmación «tanto en el supuesto de las Salas que no tengan Sección como en el caso de que tengan más de una Sección» nos suscita numerosas dudas. Entendemos que se refiere a lo dispuesto en el artículo $86.3,3 .^{\circ}$ párrafo LJCA, que se pronuncia en los siguientes términos: «si la Sala o Salas de lo Contencioso-administrativo tuviesen más de una Sección, la Sala de Gobierno del Tribunal Superior de Justicia establecerá para cada año judicial el turno con arreglo al cual los Presidentes de Sección ocuparán los puestos de la regulada en este apartado. También lo establecerá entre todos los Magistrados que presten servicio en la Sala o Salas».

Cabe plantearse si el Tribunal Constitucional está reconociendo que la Sección Casacional ha de constituirse también cuando el Tribunal Superior de Justicia esté formado por una única Sala y Sección, pues en el ATC de 16 de abril de 2018 parece inclinarse por otra opción al mantener que es razonable no constituirla en esos casos. No alcanzamos a descifrar adecuadamente esta afirmación, pero la sentencia que aquí analizamos parece inclinarse por la postura adoptada en el citado Auto, ya que se ha defendido en ella que la Sección Casacional estaría compuesta siempre de Magistrados del mismo orden, lo que nos lleva a considerar que el Tribunal Constitucional parte de la premisa de que la casación autonómica solo ha de reconocerse en el ámbito jurisdiccional de Tribunales Superiores de Justicia de varias Salas y/o Secciones, que son los que a priori no presentan escasez de medios personales.

Esta premisa podría confirmarse si uno se detiene en la lectura del siguiente párrafo: «el ATC 41/2018 reconoció la razonabilidad de la interpretación acogida por el Tribunal Superior de Justicia de Extremadura ante la imposibilidad de constituir la Sala de Recursos en aquellos Tribunales Superiores en los que la Sala de lo Contencioso-Administrativo solo disponga de una Sección. Pero esta dificultad no concurre en aquellos Tribunales que, como el que plantea la actual cuestión de inconstitucionalidad, disponen de una pluralidad de Secciones».

Es curioso que se realicen estas afirmaciones, pues parece desvelar el Tribunal Constitucional que la justificación de que no se admita el recurso en los Tribunales Superiores de Justicia de Sala y Sección única se encuentra en cuestiones organizativas, en «la imposibilidad de constituir» la misma en estos casos. Y ello choca con lo que se mantuvo en aquel ATC, en el que el Tribunal Constitucional había descartado que el Tribunal Superior de Justicia de Extremadura hubiese negado el derecho a un recurso previsto legalmente por razones organizativas, pues a su juicio la razón de inadmisión del recurso descansaba en la negación de la viabilidad del recurso en su ámbito jurisdiccional por razones de finalidad. 
Afirmó en dicha resolución, lo siguiente: «En este razonamiento mantenido por el Auto impugnado no se apela a razones organizativas para justificar la inadmisión del recurso, sino que se considera que el recurso de casación autonómico, en el caso, al no resultar idóneo para cumplir la función inherente a su naturaleza, carece de razón de ser. A partir de aquí, la Sala obtiene la conclusión, que se apoya también en el tenor literal del artículo 86.3 LJCA, de que este recurso "está pensado para los casos de un Tribunal Superior de Justicia que dispone de varias Salas de lo Contencioso-Administrativo o de varias Secciones dentro de la misma Sala". Y dicha conclusión, que lleva a estimar inadmisible el recurso de casación preparado, se valora como producto de una exégesis racional de los preceptos legales aplicables...».

A nuestro juicio, si la causa de la denegación del recurso de casación autonómico se basa meramente en cuestiones organizativas, se estaría produciendo una vulneración del derecho a la tutela judicial efectiva en el derecho de acceso a los recursos. Si la razón de denegación es el incumplimiento de la finalidad asignada -«formación de jurisprudencia»-, al interpretarse estrictamente el mandato legislativo, no habría que hacer distinciones entre Tribunales Superiores de Justicia. Tengan una o varias Salas o Secciones la finalidad es irrealizable en la mayoría de las ocasiones si ya se ha establecido la doctrina en la instancia y no es necesario matizarla, precisarla o corregirla ${ }^{28}$.

\section{REFLEXIONES FINALES}

Del examen de los pronunciamientos aquí realizado se desprende que el Tribunal Constitucional se ha pronunciado, en rotundos términos, a favor de la constitucionalidad de la casación autonómica. Según su criterio, no se ha vulnerado la reserva de ley orgánica prevista en el artículo 122 CE al establecerse la Sección Casacional por ley ordinaria, ni el principio de seguridad jurídica dado que pueden aplicarse mutatis mutandis los preceptos reguladores de la casación estatal si surgen dudas interpretativas. Tampoco se infringe el principio de igualdad cuando las disparidades interpretativas provienen de distintos órganos judiciales y resulta razonable que los Tribunales Superiores de única Sala y Sección no admitan el recurso frente a sus propias resoluciones.

Cabe pensar que algo está fallando, cuando la interpretación del derecho de acceso a los recursos que se enmarca dentro del derecho a la tutela judicial efectiva no permite acceder al recurso en determinados ámbitos jurisdiccionales, a pesar de que el tratamiento debiera ser el mismo para todos dado que la regulación no hace distinciones; cuando se controla solo la razonabilidad y no el acierto del razonamiento ${ }^{29}$ y cuando el principio de igualdad del artículo 14 CE, interpretado por nuestro órgano constitucional avala la disparidad interpretativa en torno a una misma regulación por razones de independencia judicial.

Después del beneplácito constitucional a la regulación de la casación autonómica y a la diversidad interpretativa, con la consiguiente perpetuación que ello supondrá; y después de que se haya constado que el Tribunal Supremo no dispone de cauce para interpretar armónicamente la regulación de la casación autonómica ${ }^{30}$, la inseguridad jurídica que, a nuestro juicio, sí se produce a la hora de aplicar dicha normativa, está llamada a continuar.

Aquel recurrente que se vea privado del recurso de casación autonómico en Tribunales Superiores de Justicia de Sala y Sección única no verá satisfechas, previsiblemente sus pretensiones en la jurisdicción constitucional. Sin embargo, aún podría intentar con éxito, si la inadmisión se ha debido a causas meramente organizativas, la invocación ante el TEDH de la vulneración del artículo $6 \mathrm{CEDH}$.

28 El argumento acerca de que la denegación por razones de incumplimiento de la finalidad no entraña necesariamente una vulneración del derecho a la tutela judicial efectiva, que aparentemente maneja el Tribunal Constitucional, aunque la verdadera causa de la inadmisión se encuentra, a nuestro juicio, en razones organizativas, se concilia con la doctrina contenida en la STC de 15 de septiembre de 2003 (Sala Primera) (núm. Rec. 2235/1998) (RTC 2003/157). Según esta Sentencia, «la decisión judicial de inadmisión del recurso, como toda decisión judicial, ha de estar fundada en Derecho, lo que no supone, sin embargo, que haya de apoyarse necesariamente en un precepto de un texto normativo escrito, sino, simplemente, que debe encontrar fundamento en el Ordenamiento jurídico. Por eso, es perfectamente aceptable que la causa de inadmisión aplicada resulte de la configuración esencial del recurso en cuestión».

${ }_{29}$ Al respecto, vid. CHAVES GARCÍA, J. R. "El recurso de casación autonómico desamparado por el Tribunal Constitucional", dirección URL: https://delajusticia.com/2018/06/14/el-recurso-de-casacion-autonomico-desamparado-por-el-tribunal-constitucional/.

30 Se desprende ello de la lectura del ATS de 5 de junio de 2017 (Sala de lo Contencioso-Administrativo, Sección 1. ${ }^{\text {a) }}$ (núm. Rec. 307/2017) (JUR 2017/148810) y del ATS de 11 de junio de 2018 (Sala de lo Contencioso-Administrativo, Sección 1.a) (núm. Rec. 143/2018) (JUR 2018/172537). También, QUINTANA CARRETERO, J. P., CASTILLO BADAL, R., y ESCRIBANO TESTAUT, P., habian apuntado esta falta de cauce a los efectos de lograr paz interpretativa, vid. Guía Práctica del recurso de casación contenciosoadministrativo, op. cit., pág. 402. 
REALA. Nueva Época - N. ${ }^{\circ}$ 11, Abril-Septiembre 2019 - ISSN: 1989-8975 - DOI: 10.24965/reala.v0i11.10660 - [Págs. 75-95]

La disparidad de criterios interpretativos en torno a la casación autonómica y su enjuiciamiento constitucional en el ATC de 16 ...

Estefanía Álvarez Menéndez

Es cierto que conforme a este precepto cabe limitar el derecho de acceso a un Tribunal, pero estas limitaciones solo se concilian con él «si persiguen un objetivo legítimo y si existe una relación razonable de proporcionalidad entre los medios empleados y el objetivo perseguido». Y, además, en ningún caso, debe restringirse "el acceso abierto al individuo de tal modo o a un punto tal que se viole el derecho en su propia esencia» ${ }^{31}$.

Ciertamente, consideramos que, de negarse el acceso a la casación autonómica por razones organizativas, podría entender el TEDH vulnerado el derecho de acceso en su propia esencia. No en vano, la STEDH de 23 de octubre de 2018, Caso Arrozpide Sarasola y otros contra España, (Sección 3. ${ }^{a}$ ) (TEDH 2018/102) considera que ello acontece «cuando su regulación deja de servir al objetivo de la seguridad jurídica y la correcta administración de justicia y constituye una especie de barrera que impide al litigante que su litigio sea examinado sobre el fondo por el órgano jurisdiccional competente (K. contra Turquía [GS], núm. 8917/05 (JUR 2009/473423) , ap. 79, TEDH 2009 (extractos))».

Más allá de cualquier compostura que se realice, la discusión acerca de la aplicación de la casación autonómica no podrá darse por zanjada hasta que el legislador no tome conciencia de que es irrazonable articular un recurso que tiene por finalidad formar jurisprudencia frente a sentencias del propio Tribunal Superior de Justicia que ya establecen la misma. Debe recuperarse el recurso de casación autonómico para la unificación de doctrina frente a dichas sentencias y mantener el recurso de casación autonómico, aunque dotándolo de la debida regulación procedimental, frente a las sentencias de los Juzgados de lo Contencioso-Administrativo ${ }^{32}$.

\section{REFERENCIAS BIBLIOGRÁFICAS}

ALONSO MURILLO, F. (2016): "El nuevo recurso de casación contencioso-administrativo en materia tributaria", en $A E D A F$, núm. 9, Madrid.

ÁLVAREZ MENÉNDEZ, E. (2018): "El recurso de casación autonómico", en El recurso de casación en materia tributaria. Cizur Menor: Aranzadi.

CUDERO BLAS, J. [2016]: "El recurso de casación por infracción de normas autonómicas", en El Derecho, dirección URL: http://www.elderecho.com/tribuna/administrativo/recurso-casacion-infraccion-normasautonomicas_11_982180001.html.

CHAVES GARCÎA, J. R. [2017]: "Si un extraterrestre observase el recurso de casación contencioso-administrativo", dirección URL: https://delajusticia.com/2017/03/24/si-un-extraterrestre-observase-el-recurso-de-casacioncontencioso-administrativo.

CHAVES GARCÍA, J. R. [2018]: "El recurso de casación autonómico desamparado por el Tribunal Constitucional", dirección URL: https://delajusticia.com/2018/06/14/el-recurso-de-casacion-autonomico-desamparado-por-e/tribunal-constitucional/.

QUINTANA CARRETERO, J. P., CASTILLO BADAL, R. y ESCRIBANO TESTAUT, P. (2016): Guía Práctica del recurso de casación contencioso-administrativo (coord. QUINTANA CARRETERO, J. P.). Madrid: Dykinson.

RAZQUIN LIZARRAGA, J. A. (2016): "Problemas del nuevo recurso de casación contencioso-administrativo", en Revista Aranzadi Doctrinal, núm. 11, Aranzadi.

REQUERO IBÁÑEZ, J. L. (2016): "La reforma de 2015 del recurso de casación en la jurisdicción contenciosoadministrativa", en Cuadernos Digitales de Formación, núm. 25, Consejo General del Poder Judicial.

RIVERO GONZÁLEZ, M. (coord.) (2012): "El nuevo régimen de los recursos extraordinarios en la jurisdicción contencioso-administrativa", en Comentarios a la Ley de la Jurisdicción Contencioso-Administrativa de 1998, 5. ${ }^{a}$ ed. Pamplona: Aranzadi.

RODRÍGUEZ PUÑAL, E. (2017): “La imprecisa regulación del recurso de casación autonómico", en Actualidad Jurídica Aranzadi, núm. 926, Aranzadi.

SOSPREDRA NAVAS, F. J. (2017): "El controvertido ámbito de las resoluciones recurribles en el recurso de casación contencioso-administrativo", en Revista Aranzadi Doctrinal, núm. 3, Aranzadi.

31 Sobre este particular, puede consultarse las siguientes Resoluciones: STEDH de 15 de febrero de 2000, Caso García Manibardo contra España (Sección 4. ${ }^{a}$ ) (TEDH 2000/7), STEDH de 28 de octubre de 2003, Caso Stone Court Shipping Company S. A. contra España (Sección 4. ${ }^{a}$ ) (TEDH 2003/61), STEDH de 24 de mayo de 2006, Caso Liakopolou contra Grecia (Sección 1. ${ }^{a}$ ) (JUR 2006/173704) y, entre otras, STEDH de 7 de julio de 2015, Caso Shamoyan contra Armenia (Sección 3. ${ }^{a}$ ) (TEDH 2015/101).

32 Esta es la solución que planteó en su momento, aunque finalmente no llegaría a ver la luz, el "Informe explicativo y Propuesta de anteproyecto de ley de eficiencia de la Jurisdicción contencioso-administrativa", elaborado por la Sección especial para la reforma de la Ley de la Jurisdicción contencioso-administrativo, constituida en el seno de la Comisión General de Codificación por Orden Ministerial de 11 de julio de 2012. De igual modo, tras la entrada en vigor del citado recurso, apostó por ella nuestro Alto Tribunal en el "Documento de Trabajo de la Sala Tercera del Tribunal Supremo sobre los problemas interpretativos de la nueva regulación de la casación contencioso-administrativo", y en concreto, su Propuesta de reforma de la Disposición Final Tercera de la Ley Orgánica 7/2015, de 21 de julio, que se acompaña al mismo. 